\title{
PRIPADNICI AUSTROUGARSKE MORNARICE I ČITANJE U PRVOM SVJETSKOM RATU: PRIMJER SPLITSKE KNJIŽARE MORPURGO
}

Jelena LAKUŠ

Filozofski fakultet

Sveučilišta Josipa Jurja Strossmayera u Osijeku

Osijek, Hrvatska

Nada TOPIĆ

OŠ Vjekoslava Paraća

Solin, Hrvatska
UDK: 359(436-89):655.4(497.5Split)(091)

DOI: https://doi.org/10.21857/yq32oh47g9

Izvorni znanstveni rad

Prihvaćeno: 12. siječnja 2018.

U radu se analiziraju narudžbenice koje su pripadnici austrougarske mornarice uputili splitskoj Knjižari Morpurgo u razdoblju od 1914. do 1916. godine, a koje otkrivaju niz podataka o vojnicima kao čitateljima: njihova imena, status, imena brodova i vojnih baza u kojima su bili smješteni, naslove publikacija koje su naručili, a ponekad i zašto su čitali, dajući nam tako važan uvid u čitateljski profil vojnika u vrijeme Prvog svjetskog rata.

Ključne riječi: vojnici, austrougarska mornarica, Prvi svjetski rat, Knjižara Morpurgo, čitanje, čitateljska kultura.

\section{UVOD}

Kada je 1986. godine Robert Darnton u svojoj danas često citiranoj metodološkoj raspravi First Steps Toward a History of Reading upozorio na to da sve ima svoj historijat, pa tako i čitanje, otvoreno je novo poglavlje u proučavanju povijesti knjige. ${ }^{1}$ Istraživački se interes znanstvenika postupno počeo pomicati $s$ proučavanja problematike autorstva, tiskarstva, izdavaštva i knjižarstva, važnih, ali ne i jedinih segmenata Darntonova komunikacijskog ciklusa knjige, ${ }^{2}$ na čitatelje i čitanje kao društveni fenomen i vid društvene prakse, koja se kroz povijest mijenjala i poprimala različite oblike među različitim društvenim grupama. ${ }^{3}$ „Historičnost“ čitatelja dotad se uglavnom nije prepoznavala ili je

1 Robert Darnton, First Steps Toward a History of Reading, u: The Kiss of Lamourette. Reflections in Cultural History, ur. Robert Darnton, New York, 1990., 155. Članak je prvi puta objavljen u časopisu Australian Journal of French Studies 1986. godine.

2 Robert Darnton, What is the History of Books?, u: The Kiss of Lamourette. Reflections in Cultural History, ur. Robert Darnton, New York, 1990., 112.

3 R. DARnton, First Steps Toward a History of Reading, 166. 
bila neopravdano zanemarivana. Studije iz područja povijesti knjige čitatelje su mahom zaobilazile problematizirajući ih jedino u kontekstu njihove uloge koju na knjižnom tržištu obnašaju kao potencijalni kupci knjige prema čijim literarnim, znanstvenim i obrazovnim potrebama izdavači, tiskari i knjižari oblikuju svoj nakladnički plan ili knjižarsku ponudu. ${ }^{4}$ Sažimajući različite zadatke i smjerove povijesti čitanja u pitanja tko je što, gdje, kada, zašto i kako čitao, ${ }^{5}$ Darnton, uz makroanalitički, predlaže i mikroanalitički pristup, koji nastoji donijeti zaključke o čitateljskim navikama pojedinaca ili pojedinih struktura društva. ${ }^{6}$ Zadatak povijesti čitanja Roger Chartier vidi u identifikaciji specifičnih mehanizama „koji razlikuju različite zajednice čitatelja i tradicije čitanja“7 Čitateljske se prakse naime mogu kretati od pojedinačnih i subjektivnih prema onima koje bi mogle biti karakteristične za različita povijesna razdoblja i različite društvene grupe (redovnike i svećenike, plemiće, pripadnike građanskih krugova, žene, djecu itd.).

Kao specifična društvena grupa i zasebna kategorija čitatelja javljaju se i vojnici. Njihove su čitateljske navike, posebno u razdoblju dvaju velikih svjetskih ratova 20. stoljeća, bile predmetom interesa niza inozemnih povjesničara knjige i čitanja. Prigodom obilježavanja stogodišnjice početka Prvog svjetskog rata taj je interes ponovno oživio. Najveći je broj radova posvećen tzv. „frontaškim“ ili „rovovskim“ i „Vojničkim“ novinama koje su bile neodvojiv dio vojničkog života na obje zaraćene strane te su stoga vrlo često i analizirane iz komparativne perspektive. ${ }^{8}$ Podjednak je i broj radova koji razotkrivaju čitateljska iskustva i prakse vojnika (što, kada, gdje, kako, pa čak i zašto čitaju), bilo da je riječ o vojnicima kao korisnicima knjižnica ${ }^{9}$ ili o ratnim zatvorenicima koji su također velik dio svoga vremena u

4 Ian JACKson, Approaches to the History of Readers and Reading in the Eighteenth Century Britain, The Historical Journal, sv. 47, br. 4, Cambridge, 2004., 1044.

5 R. DARnton, First Steps Toward a History of Reading, 157.

6 R. Darnton, First Steps Toward a History of Reading, 162.

7 Robert Chartier, The Order of Books: Readers, Authors, and Libraries in Europe Between the Fourteenth and Eighteenth Centuries, Stanford, 1994., 4.

8 Vidi primjerice: Nick Hiley, You Can't Believe a Word You Read: Newspaper-reading in the British Expeditionary Force, 1914-1918, Media History, sv. 2, br. 1-2, 1994., 89 - 102; Robert L. Nelson, Soldier Newspapers: A Useful Source in the Social and Cultural History of the First World War and Beyond, War in History, sv. 17, br. 2 , New York, 2010., 180 - 182; Robert L. Nelson, German Soldier Newspapers of the First World War (Studies in the Social and Cultural History of Modern Warfare), New York, 2011.; Graham SeAL, The Soldiers' Press: Trench Journals in the First World War, Basingstoke, 2013.; Graham SEAL, 'We're Here Because We're Here': Trench Culture of the Great War, Folklore, sv. 124, br. 2, London, 2013., 178 - 199.

9 Edmund G. C. KInG, E. W. Hornung's Unpublished „Diary“, the YMCA, and the Reading Soldier in the First World War, English Literature in Transition, 1880-1920, sv. 57, br. 3, Baltimore, 2014., 361 - 387; Amanda Laugesen, Finding „Another Great World“: Australian Soldiers and Wartime Libraries, Library Quaterly, sv. 76, br. 4, Chicago, 2006., 420 - 437. 
zatočeništvu posvećivali čitanju. ${ }^{10}$ Pronalazimo i radove koji se bave djelovanjem knjižnica u vrijeme Prvog svjetskog rata te ulozi koju su u poticanju čitanja među vojnicima knjižničari obnašali u ratno vrijeme. ${ }^{11}$ Naposljetku, kulturi čitanja među vojnicima pristupalo se i s niza različitih drugih aspekata, kao što su primjerice čitanje i literarni kanon, ${ }^{12}$ čitanje i nacionalni identitet, čitanje i identitet grupe ${ }^{13}$ itd., pri čemu su ratni dnevnički zapisi, memoari i korespondencija suvremenika svakako najčešće korišteni izvori.

Povijest čitanja u Hrvatskoj međutim još je u začetcima. Kada je 1993. godine objavljena selektivna retrospektivna bibliografija Grada za bibliografiju proučavanja čitanja u Hrvatskoj i ostalim južnoslavenskim zemljama (osim Bugarske) 1862.-1990., o istraživanju povijesti čitanja u „darntonovskoj“ maniri tada još nije bilo ni govora. ${ }^{14}$ Ipak, u nedavno objavljenoj knjizi Davida Šporera Uvod u povijest knjige: temelji pristupa (2015.), zamišljenoj „kao uvod u jednu vrstu 'pristupa' interakciji knjige i društva u povijesnoj perspektivi“, ${ }^{15}$

10 Vidi primjerice: Edmund G. C. KInG, Books Are More to Me Than Food: British Prisoners of War as Readers, 1914-18, Book History, sv. 16, Baltimore, 2013., 247 - 271; Edmund G. C. KING, A Captive Audience? The Reading Lives of Australian Prisoners of War, 1914-1918, u: Reading and the First World War: Readers, Texts, Archives, ur. Shafquat Towheed i Edmund King, Basingstoke, 2015.

11 Knjižničari su smatrali da čitanje osnažuje osjećaj domoljublja i zajedništva te ubrzava fizički i psihički oporavak vojnika nakon ranjavanja. Uz to, vojsku koja čita, istaknuto je primjerice na godišnjoj konferenciji Američkog knjižničarskog društva 1917. godine, naprosto se ne može pobijediti. Vidi primjerice: Kathy L. Souers, The Library and the Community it Serves in Times of War: Everything Old is New Again, Florida Libraries, sv. 47, br. 2, Tallahassee, 2004., 16 - 19; Caroline Daniels, The Feminine Touch Has Not Been Wanting: Women Librarians at Camp Zachary Taylor, 1917-1919, Libraries \& Cultural Record, sv. 43, br. 3, Austin, 2008., 286 307; Marcela P. Sutcliffe, Reading at the Front: Books and Soldiers in the First World War, Paedagogica Historica, sv. 52, br. 1/2, Gent, 2016., 104 - 120; Loretta de Franceschi, Scientific, Educational and Pleasure Reading for Young Italian Soldiers: 1900-1920, History of Education \& Children's Literature, sv. 6, br. 2, Macerata, 2011., $261-280$.

12 Edmund G. C. KIng, A Priceless Book to Have Out Here: Soldiers Reading Shakespeare in the First World War, Shakespeare, sv. 10, br. 3, Abingdon, 2014., 230 - 244.

13 S. Towheed, E. King, ur. Reading and the First World War: Readers, Texts, Archives, Basingstoke, 2015.

14 Autorice prikupljenu građu dijele u šesnaest nizova (npr. andragogijski aspekt čitanja, biblioterapeutski način čitanja, informatički aspekt čitanja, izdavalački aspekt čitanja, književni aspekt čitanja, knjižničarski aspekt čitanja, kulturno-povijesni aspekt čitanja, pedagogijski aspekt čitanja, sociologijski aspekt čitanja itd.). Bibliografija „vjerno i realno prikazuje kako je problematika čitanja u nas tradicionalno marginalizirana, sporo evaluirala i dugo ostajala "prikrivenom" unutar drugih disciplina“. Đurđa Mesić, Danko Plevnik, Dijana Sabolović-Krajina, Građa za bibliografiju proučavanja čitanja u Hrvatskoj i ostalim južnoslavenskim zemljama (osim Bugarske) 1862.-1990., Informatologia, sv. 25, br. 3-4, Zagreb, 1993., 45 - 48.

15 David ŠPorer, Uvod u povijest knjige: temelji pristupa, Zagreb, 2015., 9. 
povijesti je čitanja, na teoretskoj razini, posvećeno cijelo poglavlje simbolično nazvano „Zvuk tišine“. ${ }^{16}$ „Povijest čitanja može se razumjeti kao zasebni pristup ili područje istraživanja koje se gotovo izdvaja iz povijesti knjige. Ali isto tako može se uzeti da ona predstavlja samo privremenu konstrukciju neodvojivu od povijesti knjige jer se i njezin pristup i teme toliko isprepliću s poviješću knjige općenito da se radi tek o pomicanju naglaska u nekom konkretnom kontekstu poučavanja, u nekoj pojedinoj studiji ili članku“, ${ }^{17}$ piše Šporer navodeći u poglavlju neke od inozemnih i domaćih autora koji su o čitanju kroz povijest promišljali na teoretskoj, metodološkoj ili pak konkretnoj, istraživačkoj razini. Šporer međutim gotovo da u potpunosti izostavlja „oca“ povijesti knjige u Hrvata - Aleksandra Stipčevića, koji u svojim djelima, poglavito u trodijelnoj sintezi Socijalna povijest knjige u Hrvata (2004. - 2008.) identificira neke od fenomena u povijesti čitanja u Hrvata: čitanje i slušanje, korist i štetnost od čitanja knjiga, hrvatski narodni preporod i čitanje, čitanje knjiga na stranim jezicima, čitanje i javne knjižnice i čitaonice, struktura čitatelja i slično. ${ }^{18}$

Iako su Stipčevićeva djela trasirala put budućim istraživačima, još uvijek su radovi iz područja povijesti čitanja malobrojni i uglavnom usmjereni na proučavanje individualnih praksi čitanja. ${ }^{19}$ Međutim, čitateljskim praksama pojedinih društvenih kategorija, s iznimkom nekoliko radova o čitanju djece i mladih u 19. stoljeću, ${ }^{20}$ do sada u Hrvatskoj nije posvećena gotovo nikakva

16 D. ŠPORER, Uvod u povijest knjige, $281-319$.

17 D. ŠPORER, Uvod u povijest knjige, 281.

18 Aleksandar Stipčević, Socijalna povijest knjige u Hrvata. Knjiga I. Srednji vijek, Zagreb, 2004.; Aleksandar STiPČEvić, Socijalna povijest knjige u Hrvata. Knjiga II. Od glagoljskog prvotiska (1483) do hrvatskoga narodnog preporoda (1835), Zagreb, 2005.; Aleksandar STiPČEvić, Socijalna povijest knjige u Hrvata. Knjiga III. Od početaka hrvatskoga narodnoga preporoda (1835.) do danas, Zagreb, 2008.; Aleksandar STipčEvić, Sudbina knjige, Lokve, 2000.; Aleksandar STiPČEvić, O savršenom cenzoru iliti Priručnik protiv štetnih knjiga i njihovih autora, Zagreb, 1994.

19 Nada Topić, Profil profesionalnog čitatelja: čitateljske prakse Ive Vojnovića, Libellarium, sv. 3, br. 2, Zadar-Osijek, 2010., 153 - 182; Dinko Župan, "Books I have read“ - Dora Pejačević kao čitateljica, Scrinia Slavonica, sv. 12, Slavonski Brod, 2012., 115 -178; Jelena LAKuš, Anita BAJIć, Dnevnik Dragojle Jarnević kao izvor za povijest knjige i čitanja, Književna smotra: časopis za svjetsku književnost, sv. 46, Zagreb, 2014., 129 - 143; Jelena LAKuš, Anita BAJıć, Interpreting Diaries: History of Reading and the Diary of the Nineteenth-Century Croatian Female Writer Dragojla Jarnević, Information \& Culture, sv. 52, br. 2, Austin, 2017, 163 - 185.

20 Marijana HAmeršak, Višestruki odnosi i neočekivani ishodi: prvo stoljeće hrvatske dječje književnosti iz vizure povijesti čitanja, knjige i djetinjstva, Časopis za suvremenu povijest, sv. 41, br. 3, Zagreb, 2009., 783 - 804; Marijana HAMEršA , Pričalice: o povijesti djetinjstva $i$ bajke, Zagreb, 2011.; Jelena LA KUŠ, Čuvari javnog ćudoređa: crkveno-vjerska i pedagoška nastojanja oko oblikovanja čitateljskih navika hrvatske mladeži 19. stoljeća, Croatica Christiana Periodica, sv. 37, br. 71, Zagreb, 2013., 103 - 127. 
pozornost, pa tako ni čitateljskim praksama vojnika. ${ }^{21}$ Iako je 2014 . godina bila u znaku stote obljetnice početka Prvog svjetskog rata te obilježena u gotovo svim hrvatskim gradovima velikim brojem znanstvenih skupova i događanja u nizu kulturnih i obrazovnih ustanova, ${ }^{22}$ čitanju u ratnim vremenima nije dana nikakva pozornost, osim u kontekstu novinskog izvještavanja o ratu i/ ili interesu novinskog čitateljstva za ratnim vijestima, ${ }^{23}$ ili pak novinskim sadržajima koji su služili za razbibrigu od ratne svakodnevice, ${ }^{24}$ ili pak u kontekstu produkcije djela koja su odisala duhom ratne promidžbe „za kralja i dom". ${ }^{25}$ Stoga su u nas obilježja čitateljskih praksi vojnika u vrijeme Prvog svjetskog rata gotovo potpuna nepoznanica. Radovi koji postoje usmjereni su ponajprije na kulturno, prosvjetno ili domoljubno djelovanje knjižnica i čitaonica ${ }^{26}$ ili pak samo daju pregled povijesnog razvoja infrastrukture kulture čitanja potkraj 19. i početkom 20. stoljeća, pa tako i u vrijeme Prvog svjetskog rata. ${ }^{27}$ Međutim, oni ne govore gotovo ništa o čitateljskim praksama, iskustvima i navikama vojnika u tim ratnim vremenima.

21 Bilježimo tek desetljećima star magistarski rad Vladimira Babića. Vladimir BABIĆ, Čitanje u JNA. Neka teorijska razmatranja i empirijska verifikacija: magistarski rad, Zagreb, 1976.

22 Cjelokupan popis raznovrsnih projekata pokrenutih u cilju obilježavanja stogodišnjice Prvog svjetskog rata, poduprtih od strane Ministarstva kulture Republike Hrvatske, vidi na: Ministarstvo kulture Republike Hrvatske. Prvi svjetski rat: sto godina poslije. Popis projekata, posjećeno 25. 3. 2017., http://www.min-kulture.hr/default.aspx?id=10790

23 Vidi primjerice: Ljiljana DobrovšAK, Pozadina izlaženja Ilustrovanoga lista - izvora za povijest Prvoga svjetskog rata, u: 1914. Prva godina rata u Trojednoj Kraljevini i Austro-Ugarskoj Monarbiji: zbornik radova, ur. Vijoleta Herman Kaurić, Zagreb: Matica hrvatska, 2018., 95 - 120; Tado ORšolić, Dino NeKIĆ, Početak Prvoga svjetskog rata i dalmatinske postrojbe 1914. - problem pouzdanosti novinskih vijesti, u: 1914. Prva godina rata u Trojednoj Kraljevini i Austro-Ugarskoj Monarbiji, 209 - 231; Marko VukičEvić, Prvi mjeseci Velikoga rata - prikaz rata u medijskom prostoru grada Zagreba, u: 1914. Prva godina rata u Trojednoj Kraljevini i Austro-Ugarskoj Monarbiji, 487 - 500.

24 Ela JURDANA, Zagrebački ilustrirani listovi 1914.-1918.: „Lungenšpicnkatar“ i druge teme u vrijeme Prvog svjetskog rata, Zagreb, 16. - 17. prosinca 2014., u: Zagreb u Prvom svjetskom ratu: program skupa i sažeci izlaganja, Zagreb, Filozofski fakultet Sveučilišta u Zagrebu, 2014., 9 - 10, posjećeno 25. 3. 2017., http://www.ffzg.unizg.hr/wp-content/uploads/2014/12/Programska-knji\%C5\%BEica.pdf.

25 Željko Holjevac, Hrvatske pjesme na početku rata 1914. - između zvučne promidžbe i krvave stvarnosti, u: 1914. Prva godina rata u Trojednoj Kraljevini i Austro-Ugarskoj Monarhiji, 371 - 382.

26 Vidi primjerice: Bruno DoBRIĆ, ur., Čitaonički i knjižnični pokret u Hrvatskoj u 19. i 20. stoljeću: zbornik radova sa znanstvenog skupa, Pazin, 15. studenog 1993., Pula, 1996.; Bruno Do BRIĆ, Hrvatska čitaonička društva u Istri u 19. i početkom 20. stoljeća, Pula, 1993.; Bruno DoBRIć, ur., Mornarička knjiznnica (K. u. K. Marinebibliothek) i austrijskalaustrougarska mornarica u Puli: zbornik radova sa medunarodnog znanstvenog skupa u povodu 200. obljetnice osnutka Mornaričke knjižnice (Pula, 4. listopada 2002.), Pula, 2005.

27 Bruno DoBrić, Kultura čitanja i nacionalni pokreti: čitalačka društva i knjižnice u Puli u drugoj polovici 19. i prvoj polovici 20. stoljeća, Pula, 2003.; Walter WAGNER, Bruno DoBrIć, Mornarička knjižnica: knjižnica austrougarske Mornarice, Pula, 1997. 


\section{PRVI SVJETSKI RAT U DALMACIJI I AUSTROUGARSKA MORNARICA NA JADRANU}

Kada je u srpnju 1914. godine počeo Prvi svjetski rat, prvi globalni oružani sukob, hrvatske su se zemlje nalazile u sastavu Austro-Ugarske Monarhije te su se tako u ratu našle na strani Središnjih sila. U Puli, središnjoj luci austrougarske mornarice, još je od mirnodopskih vremena bila smještena austrougarska flota, ${ }^{28}$ uz koju su postojale još i pomoćne baze u Šibeniku i Kotoru. Prema statistici iz 1914. godine Hrvati su, zajedno sa Slovencima, u mornarici činili 34,1 \%, Mađari $20 \%$, Nijemci i Austrijanci 16,3\%, Talijani 14\%, Česi, Slovaci i Ruteni $11 \%$, a Poljaci i Rumunji 4,6\% ${ }^{29}$ Većinu časnika činili su pripadnici njemačke i mađarske nacionalnosti, uglavnom građanskog podrijetla. ${ }^{30}$ Većinu pomoraca na običnim dužnostima - mornare te dočasnički i niži časnički kadar, činili su Hrvati. Prema popisu časnika iz 1914. godine, udio Hrvata u časničkom kadru odgovarao je otprilike njihovu postotku u ukupnom udjelu stanovništva, koji je, prema popisu iz 1910. iznosio 7,9\%, zajedno sa Slovencima, ${ }^{31}$ a njihov udio među mornarima, prema popisu iz 1910. godine, iznosio je $29,8 \%{ }^{32}$ Ratne su prilike dovele do jačanja cenzure, ne samo u novinama nego i u poštanskom prometu, ${ }^{33}$ a zabilježena je i zabrana svih čitaoničkih društava koja su na bilo

28 Pula je postala središnjom lukom austrijske mornarice 1860-ih godina. U mirnodopsko vrijeme njezina je zadaća bila zaštita trgovačkog brodarstva i državne obale, organiziranje vojnih transporta i njihovo osiguranje, ali i znanstveno-istraživački rad - hidrografska, etnografska i prirodoznanstvena istraživanja Jadrana i drugih mora svijeta. Dario Pet ković, Ratna mornarica Austro-Ugarske Monarbije: brodovi u K. u. K. Kriegsmarine s prijelaza iz 19. u 20. stoljeće do kraja Prvog svjetskog rata, Pula, 2004., 46.

29 D. Petković, Ratna mornarica Austro-Ugarske Monarhije, 37.

30 Samo je manji dio, oko $10 \%$, pripadao visokoj aristokraciji i plemstvu. B. DobRIĆ, Kultura čitanja i nacionalni pokreti, 38 .

31 D. Pet ković, Ratna mornarica Austro-Ugarske Monarbije, 37 - 38. Slične podatke donosi i Zvonimir Freivogel, pozivajući se na djelo Lawrencea Sonhausa The Austro-Hungarian Naval Officer Corps, 1867-1918. te navodi da je 1910. godine udio Hrvata među časnicima iznosio 9,8\%, dok su više od polovice časnika činili Nijemci ( 51 \%). Zvonimir FreIvogel, Austrougarska vojska u Prvome svjetskom ratu, Zagreb, 2014., 238.

32 Godine 1885. godine taj je postotak bio i znatno viši, 44,9 \%. Iako je postotak Talijana 1885. godine među mornarima iznosio čak $32 \%$, on je 1910. pao na $18,3 \%$, a istodobno je porastao postotak Nijemaca: 1885. godine među mornarima je bilo 7,9 \% Nijemaca, a 1910. čak 24,5 \%. Z. Freivogel, Austrougarska vojska u Prvome svjetskom ratu, 238.

33 Odmah po početku rata uvedena je vojna preventivna cenzura koja je novinstvom neograničeno vladala preko Ratnog nadzornog ureda za tisak u Beču koji je utvrđivao što se smije objavljivati i na koji način, a što ne, a vrlo je često i nalagao što se u novinama mora objaviti, poglavito ako se ticalo ratnih događanja. Josip HoRvat, Povijest novinstva Hrvatske 1771-193, Zagreb, 2003., 330. 
koji način bila politički sumnjiva, osobito ona srpska, a po ulasku Italije u rat na strani Antante u travnju 1915. i ona talijanska. ${ }^{34}$ Iako opća mobilizacija u početku nailazi na dobar odjek, ${ }^{35}$ početno oduševljenje za rat vremenom opada pa u veljači 1918. godine bilježimo pobunu u austrougarskoj ratnoj floti u Boki kotorskoj koja je bila brzo ugušena, no pokazala je da je među austrougarskim vojnicima pred kraj rata vladalo već veliko nezadovoljstvo. ${ }^{36}$ Činjenica da je Austro-Ugarska još od kraja 19. i početka 20. stoljeća smatrana jednom od jačih pomorskih sila, rezultirala je time da pomorske snage Antante tijekom Prvog svjetskog rata nisu poduzimale veće ratne operacije na istočnoj obali Jadrana, već su svoje djelovanje ograničile na nadzor ulaza u Jadransko more kako bi spriječile prolazak austrougarskih i njemačkih podmornica na Sredozemlje. Na području Istre i Dalmacije tako tijekom Prvog svjetskog rata nije bilo većih vojnih sukoba. ${ }^{37}$ To je vojnicima, kako časnicima tako i mornarima, očito ostavljalo dovoljno slobodnog vremena i za čitanje.

\section{MORNARIČKE KNJIŽNICE I DRUGE KNJIŽNICE AUSTROUGARSKE VOJSKE I ČITALAČKA DRUŠTVA NA JADRANU}

Austrougarska mornarica posjedovala je do 1918. godine pet većih knjižnica namijenjenih isključivo mornarici. Četiri od njih nalazile su se u Puli, a jedna u Rijeci. U Puli su djelovale Mornarička knjižnica (K.u.k. Marine-Bibliothek), Knjižnica Mornaričkog kasina (Marine-Kasino Bibliothek), Knjižnica Mornaričko-tehničkog odbora i Knjižnica Carske i kraljevske Strojarske škole. U Rijeci je pak postojala Knjižnica Pomorske akademije, no ona je početkom Prvog svjetskog rata, zajedno s Akademijom, premještena u Beč. ${ }^{38}$ Središnja knjižnica Ratne mornarice i najstarija među njima bila je Mornarička knjižnica (od 1889. godine poznata kao Knjižnica Carske i kraljevske mornarice), osnovana 1802. godine. U Pulu je preseljena 1865./1866., nakon što je postala glavnom bazom austrijskog ratnog brodovlja, gdje je ostala sve do propasti

34 Filip ŠKilJaN, Prvi svjetski rat u Dalmaciji: (1914.-1918.), Split, 2014., 48, 141 - 142.

35 F. ŠKILJAN, Prvi svjetski rat u Dalmaciji, 6, 65.

36 F. ŠKILJAN, Prvi svjetski rat u Dalmaciji, 151.

37 Zvonimir Freivogel, „Crtice iz Prvog svjetskog rata u Puli i na Jadranu“, u: Carska i kraljevska mornarica u Puli $i$ na Jadranu: od 1856. do 1918. godine: pomorsko-povijesni i kulturno-povijesni prilozi, ur. Bruno Dobrić, Pula, 2014., 186.

38 Više o Vojno-pomorskoj akademiji u Rijeci, kasnije Carsko-kraljevskoj vojno-pomorskoj akademiji, vidi u: Ervin Dubrović, Vojno-pomorska akademija u Rijeci 1866-1914, Rijeka, 2011. 
Austro-Ugarske Monarhije 1918. godine. ${ }^{39}$ Bila je to znanstveno-stručna knjižnica namijenjena pomorskim, astronomskim i drugim znanstvenoistraživačkim potrebama mornarice, pa je stoga najvećim dijelom sadržavala znanstvena i stručna djela i periodiku s područja pomorstva i srodnih znanosti iz gotovo cijelog svijeta. Njezin je knjižni fond isključivao beletristiku, poeziju, lijepu književnost, umjetnost i teološka djela jer njezina je svrha, smatralo se, "koristiti, a ne služiti užitku“, ${ }^{40}$ no ipak je sadržavala i neka povijesna, zemljopisna i putopisna djela, čak i stare knjige iz 16. ili 17. stoljeća, ali i najvažnija referentna djela onoga vremena (rječnike i gramatike raznih jezika, svjetski poznate enciklopedije i leksikone) te je tako imala i općeobrazovne i humanističke značajke. ${ }^{41}$ Više od polovice knjižnog fonda činile su knjige na njemačkom jeziku, premda je bilo knjiga i na ostalim jezicima, no ponajprije na francuskom, engleskom i talijanskom. ${ }^{42}$ Knjige Mornaričke knjižnice mogle su posuđivati sve osobe koje primaju redovitu plaću Ratne mornarice, ali i pripadnici drugih rodova vojske. ${ }^{43}$ Tijekom Prvog svjetskog rata knjige su iz knjižnice mogli posuđivati čak i ratni zarobljenici. ${ }^{44}$

Kada su boravili na brodu, pripadnicima mornarice bile su dostupne i brodske knjižnice, organizirane kao podružnice Mornaričke knjižnice, koje su služile isključivo pomorskim, obrazovnim i znanstvenim potrebama ${ }^{45} \mathrm{pa} \mathrm{je}$ takav bio i njihov knjižni fond, koji je uglavnom sadržavao djela iz pomorskih znanosti, knjige o navigaciji, meteorologiji, hidrografiji, strojarstvu, nautičke tablice i slično, ali i zemljopisna, povijesna i putopisna djela. Početkom 20.

39 Detaljno o povijesti ove knjižnice, njezinu organizacijsku ustroju, knjižničnom osoblju, fondu, uređenju i poslovanju vidi u: B. DoBRIĆ, Kultura ćitanja i nacionalni pokreti, 113 - 151; W. Wagner, B. Dobrić, Mornarička knjižnica; Bruno Dobrić, Osnivanje Mornaričke knjižnice u Veneciji 1802. godine i njezino djelovanje u Puli (1856/66. - 1918.), u: Mornarička knjižnica (K. u. K. Marinebibliothek) i austrijska/austrougarska mornarica u Puli. Pula, 2005., 119 - 138.

40 W. WAgner, B. Dobrić, Mornarička knjižnica, 28.

41 W. WAgner, B. Dobrić, Mornarič̌ka knjižnica, 28, 100; B. Dobrić, Kultura čitanja i nacionalni pokreti, 122, 129 - 130.

42 Bruno Dobrić, Mornarička knjižnica i izdavaštvo C. i Kr. Mornarice u Puli, u: Carska i kraljevska mornarica u Puli i na Jadranu od 1856. do 1918. godine: pomorsko-povijesni i kulturno-povijesni prilozi, ur. Bruno Dobrić, Pula, 2014., 222.

43 B. Dobrić, Kultura čitanja i nacionalni pokreti, 131 - 132.

44 Zabilježeno je tako da je knjige iz Mornaričke knjižnice posuđivao primjerice francuski mornarički časnik O’Byren, zarobljen s podmornicom Curie potkraj 1914. godine. W. WAGNER, B. DoBRIĆ, Mornarička knjižnica, 124.

45 B. Dobrić, Kultura čitanja i nacionalni pokreti, 135 - 137. 
stoljeća bilo ih je devet i u njima se okvirno iz Mornaričke knjižnice godišnje posuđivalo oko 1000 svezaka. $^{46}$

$\mathrm{Na}$ brodovima su postojale i knjižnice osnivane pri mornarskim čitalačkim društvima, a svaki je veći brod imao i vlastitu brodsku knjižnicu. Za razliku od brodskih knjižnica, podružnica Mornaričke knjižnice, ove su knjižnice, uz stručne publikacije, sadržavale i beletristiku, koja je pripadnicima mornarice kratila vrijeme pri dužim putovanjima. ${ }^{47}$ Beletristika je, uz djela iz područja vojne i ratne znanosti i djela iz područja prirodnih i društveno-humanističkih znanosti, činila i velik dio knjižnog fonda Garnizonske knjižnice u Puli (Garnisons-Bibliothek zu Pola), osnovane 1866. godine,${ }^{48} \mathrm{u}$ koju su vjerojatno zalazili i pripadnici mornarice s obzirom na to da je u to vrijeme bio ,krajnje ograničen društveno-kulturni život u gradu i [...] da je knjižnica Mornaričkog kasina, koja je najvećim dijelom imala

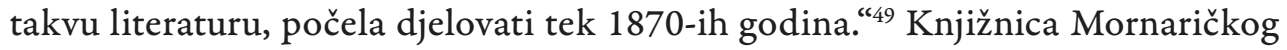
kasina bila je osnovana pri Društvu Mornarički kasino (1870.), koje je okupljalo isključivo vojnu elitu i članove njihove obitelji. ${ }^{50} \mathrm{Knjižni} \mathrm{fond} \mathrm{činila} \mathrm{je} \mathrm{uglavnom}$ beletristika, pretežito na njemačkom jeziku, ali i na drugim službeno priznatim jezicima koji su se govorili u Monarhiji. Čitaonica je pak bila bogato opskrbljena znanstvenim, političkim i književnim novinama i časopisima iz Monarhije i iz niza drugih zemalja, pa tako možemo reći da je knjižnica Mornaričkog kasina, za razliku od znanstveno-stručne naravi Mornaričke knjižnice, bila zasnovana na literarnom i općeobrazovnom načelu. ${ }^{51}$

Uz Mornaričku knjižnicu, znanstveno-stručne naravi bile su i Knjižnica Mornaričko-tehničkog odbora (Marine-technisches Komitée), Knjižnica C. i kr. Strojarske škole ( $K . u$. K. Maschinenschule) te knjižnica Znanstvenog društva c. i kr. Ratne mornarice u Puli (Wissenschaftlicher Verein der k. u. k. Kriegsmarine

46 Popis željenih djela je prije isplovljavanja sastavljao zapovjednik broda, pri čemu je bilo točno određeno koliko je knjiga svaka pojedina kategorija brodskih knjižnica mogla sadržavati, ovisno o veličini i tipu broda. Priznanicu za posudbu, čije je trajanje također bilo točno određeno, potpisivao je navigacijski časnik koji je bio odgovoran i za njihovo vraćanje u Mornaričku knjižnicu. B. DoBRIĆ, Kultura čitanja i nacionalni pokreti, 135 - 137; W. WAGNER, B. DOBRIć, Mornarička knjižnica, 108, 110, 120, 122.

47 B. Dobrić, Kultura čitanja i nacionalni pokreti, 152.

48 U Puli je, uz mornaricu, bio smješten i znatan broj pješaštva i domobranstva. Bio je to drugi po veličini garnizon u austrijskom dijelu Monarhije nakon Beča.

49 B. Dobrić, Kultura čitanja i nacionalni pokreti, 153.

so O knjižnici vidi u: B. DoBRIĆ, Kultura čitanja i nacionalni pokreti, 96 - 97, D. Petković, Ratna mornarica Austro-Ugarske Monarhije, 49 - 50; Daniel Načınović, Mornarički kasino - labirint carsko-kraljevskih uspomena, u: Carska i kraljevska mornarica u Puli i na Jadranu od 1856. do 1918. godine: pomorsko-povijesni i kulturno-povijesni prilozi, ur. Bruno Dobrić, Pula, 2014., 104 - 121.

51 B. DOBRIĆ, Kultura čitanja i nacionalni pokreti, 165. 
in Pola), koje su pripadnici mornarice zasigurno koristili. ${ }^{52} \mathrm{~S}$ obzirom na to da o njihovu djelovanju i korisnicima ne znamo mnogo, teško je međutim znati jesu li se vojnici koristili i javnim pučkim posudbenim knjižnicama koje su bile osnivane diljem Dalmacije početkom 20. stoljeća, poput pulske Biblioteca Civica (kasnije Biblioteca Comunale), osnovane 1903. godine, čiji je knjižni fond činila uglavnom beletristika, i to u najvećoj mjeri talijanska književnost, ${ }^{53}$ ili pak prve hrvatske pučke knjižnice u Puli, osnovane 1909. godine na inicijativu hrvatske inteligencije okupljene u hrvatskim kulturno-prosvjetnim društvima. ${ }^{54}$ Moguće je da su se pripadnici austrougarske mornarice, posebno oni stacionirani u Puli, služili uslugama ovih knjižnica ili pak uslugama nacionalno obojenih čitalačkih društava kojih je na području Pule i šire bilo čak nekoliko, ${ }^{55}$ a poglavito ako su ondje mogli pronaći literaturu za čitanje u slobodno vrijeme. Pouzdano se zna primjerice da su se gotovo svi austrijski mornarički i pješački viši i niži časnici učlanili u društvo Čitaonica, odmah po njegovu osnivanju 1869. godine, a neki su časnici ostali članovima i nakon što je mornarica konačno dobila vlastito mjesto okupljanja osnivanjem Mornaričkog kasina 1870. godine. ${ }^{56}$

$\mathrm{Uz}$ vojno-pomorsku i uskostručnu literaturu, literaturu društvenohumanističkog usmjerenja te beletristiku, koja im je u nekim knjižnicama bila na raspolaganju, za pripadnike mornarice objavljivale su se i posebne publikacije, tematski i sadržajno bliske životu mornara na brodu. Tako bilježimo da je 1900. godine pulski nakladnik Josip Krmpotić objavio dvije knjige na hrvatskom jeziku u kojima su, po uzoru na u narodu omiljene Kačićeve epske deseterce, opjevana pomorska putovanja austrougarskih brodova (S1. 1 i 2 ). ${ }^{57}$

52 Za oskudne podatke koje o navedenim knjižnicama postoje vidi u: B. DoBrić, Kultura čitanja i nacionalni pokreti, 97 - 98, 152.

53 Nakon što se Italija uključila u rat protiv Austro-Ugarske Monarhije 1915. godine, knjižnica je jedno kratko vrijeme tijekom Prvog svjetskog rata bila zatvorena. B. DoBRIĆ, Kultura čitanja $i$ nacionalni pokreti, $154-162$.

54 Knjižnica je bila kratkog vijeka, spaljena od strane fašista 1920. godine, zajedno s hrvatskim čitalačkim društvom Čitaonica. B. DoBRIć, Kultura čitanja i nacionalni pokreti, 168 - 172.

55 Navedena su društva, kako ona talijanska tako i ona njemačka i hrvatska, nakon ulaska Italije u rat na strani Antante 1915. godine bila ukinuta zbog političke sumnjivosti. B. DoBRIĆ, Kultura čitanja i nacionalni pokreti, 48.

56 Rad Čitaonice je, doduše, u velikoj mjeri zamro nakon evakuiranja gotovo cjelokupnog civilnog stanovništva, osim arsenalskih radnika, iz grada i okolice 1915. godine, nakon ulaska Italije u rat na strani Antante. B. DoBrić, Kultura čitanja i nacionalni pokreti, 68.

57 D. Pet Ković, Ratna mornarica Austro-Ugarske Monarhije, 55 - 56. 


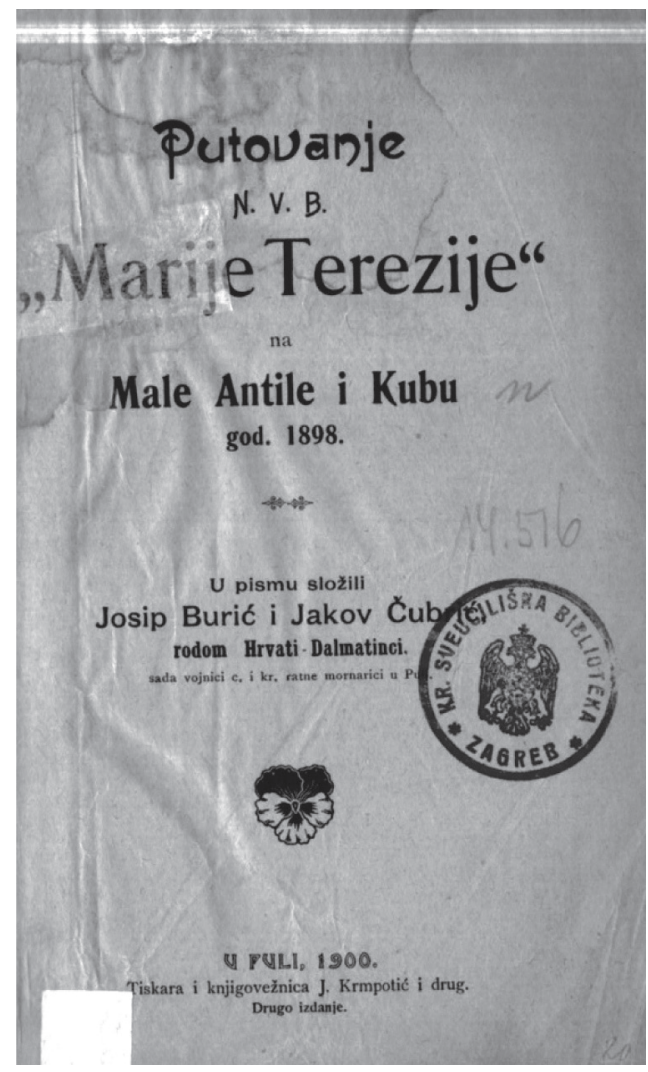

SLIKA 1. Josip BURIĆ, Jakov ČUBRIĆ, Putovanje N. V. B. "Marije Terezije“ na Male Antile i Kubu god. 1898., Pula, 1900.

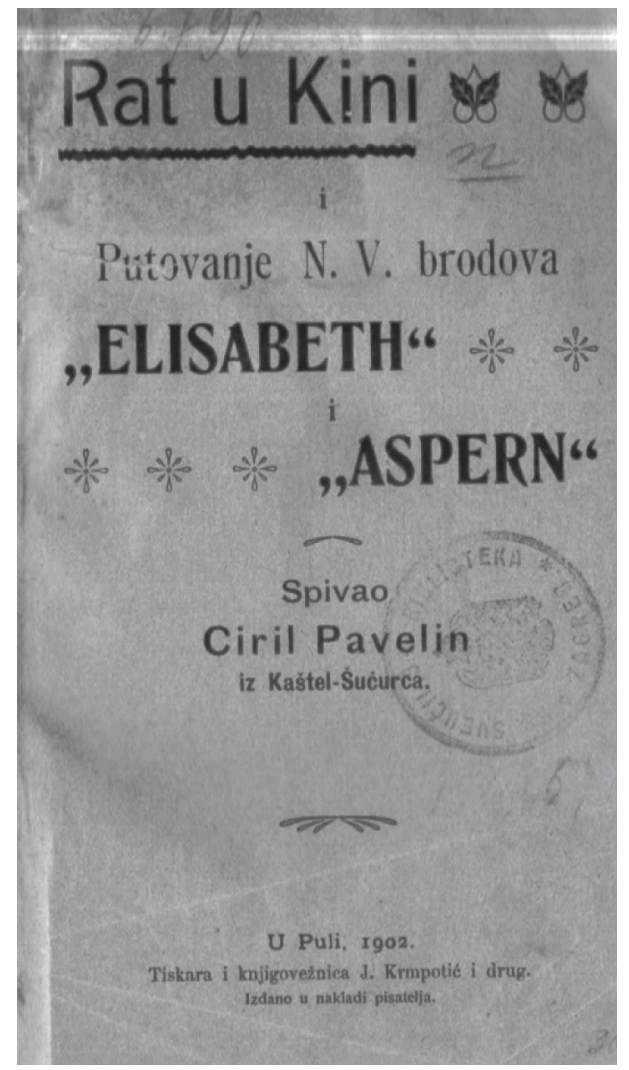

Slika 2. Ciril PAVELIN, Rat $u$ Kini $i$ Putovanje N. V. brodova "Elisabeth" $i$ „Aspern“, Pula, 1902.

Valja također spomenuti i brojne domoljubne pjesme kojima je zadatak bio dizati moral vojnicima na ratištu i njihovim obiteljima kod kuće. Iako su mnoge od njih ostale samo u rukopisnom obliku, neke su objavljivane u novinama, ${ }^{58}$ a neke i kao zasebne zbirke poezije, i to u nizu hrvatskih gradova, ali i susjednoj Bosni i Hercegovini. Pjesme nastale početkom rata su „pretežno ispjevane u duhu zvučne ratne promidžbe "za kralja i dom", iako u njima ima i dokumentarnih prikaza krvave stvarnosti na udaljenim bojištima." ${ }^{\text {"S9 }}$ Dijelom su narodne, a

58 F. ŠKILJAN, Prvi svjetski rat u Dalmaciji, 6.

59 Ž. HolJEvaC, Hrvatske pjesme na početku rata 1914., 371. 
dijelom autorske, pri čemu su neki autori bili vojnici i dočasnici u pojedinim pukovnijama na ratištu. ${ }^{60}$

Premda nakladnička djelatnost sama za sebe, pa čak i ona namijenjena isključivo mornarima i časnicima, ${ }^{61}$ ne govori mnogo o njihovim čitateljskim praksama i iskustvima, jednako kao ni knjižni fond mornaričkih i drugih knjižnica, pouzdano znamo da su vojnici čitali, o čemu svjedoče sâmi suvremenici, ali i novinski napisi iz toga vremena, na koje možemo sporadično naići. Tako primjerice hrvatski književnik i znanstvenik Mijo Mirković, koji je 1918. u Puli služio u austrougarskoj mornarici, svjedoči da su časnici mornarice, „živeći na brodovima s mnogo vremena za sebe i znajući jezike (...) u velikom broju mnogo čitali (...) i stručne knjige i beletristiku. “62 Bilježimo također da je Hrvatska knjižara u Splitu krajem 1917. godine poklonila 50 knjiga za zarobljenike u „neprijateljskim zemljama“, koje su im se organizirano slale u paketima, ${ }^{63}$ a knjige su stizale i iz Dubrovnika. ${ }^{64}$ Međutim, kako ne znamo o kojim je naslovima i autorima riječ, ${ }^{65}$ sačuvane narudžbe pripadnika austrougarske mornarice upućene splitskoj Knjižari Morpurgo koje takve podatke otkrivaju zasigurno će dati daleko potpuniji uvid u čitateljski profil vojnika u vrijeme Prvog svjetskog rata.

\section{NARUDŽBE PRIPADNIKA AUSTROUGARSKE MORNARICE UPUĆENE SPLITSKOJ KNJIŽARI MORPURGO (1914. - 1916.)}

Knjižara Morpurgo u Splitu bila je dobro poznata među hrvatskim pripadnicima austrougarske vojske u Prvom svjetskom ratu o čemu svjedoče

60 O književnicima u redovima austrougarske mornarice vidjeti u: D. PETković, Ratna mornarica Austro-Ugarske Monarbije, 52 - 53.

${ }^{61}$ Opširnije o njemačkom nakladništvu namijenjenom ponajprije doseljenim časnicima, vojnim i državnim činovnicima i tehničkoj inteligenciji vidi u: Bruno Dobrić, Nakladništvo na njemačkom jeziku u Puli od druge polovice 19. stoljeća do 1918. godine, Vjesnik bibliotekara Hrvatske, sv. 48, br. 3/4, Zagreb, 2005., 233 - 257; Bruno Dobrić, Novine i časopisi na njemačkom jeziku u Istri (1871.1918.): Pula, Opatija, Brijuni, Pula, 2016.

62 B. Dobrić, Kultura čitanja i nacionalni pokreti, $164-165$.

63 Smotra dalmatinska, br. 59, 25. 7. 1917.; F. ŠKILJAN, Prvi svjetski rat u Dalmaciji, 102.

64 Prava Crvena Hrvatska, br. 632, 26. 5. 1917.; F. ŠKILJAN, Prvi svjetski rat u Dalmaciji, 102.

65 Moguće je da je Hrvatska knjižara vojnicima poslala djela vjerske naravi jer joj je takvo bilo i nakladničko usmjerenje. Knjižara je naime bila prvo u vlasništvu Nadbiskupskog sjemeništa, a kada ju je 1912. godine kupila Hrvatska tiskovna zadruga, ona je nastavila tiskati djela vjerske i teološke naravi. Nada Topić, Knjižara Morpurgo u Splitu (1860. - 1947.) i razvoj kulture čitanja, Zagreb, 2017., 39. 
dopisnice i pisma upućena knjižari s njihovim narudžbama. ${ }^{66} \mathrm{U}$ Državnom arhivu u Splitu sačuvano je ukupno 113 takvih narudžbi koje datiraju u period od 1914. do 1916. godine i koje su vjerodostojan povijesni trag o potrebi za pisanom riječi i knjigom u ratnim vremenima. ${ }^{67}$ Nije poznato jesu li vojnici naručivali knjige i od drugih hrvatskih knjižara jer za sada ne postoje istraživanja koja bi to potvrdila, ali Knjižara Morpurgo bila je na dobrom glasu, posebice među mornarima, što potvrđuje nekoliko narudžbi, među ostalim i ona vojnika Lovre Školjareva s broda SMS Kaiser Franz Joseph I. ${ }^{68}$ iz Herceg Novog iz 1915. godine koji je napisao: „ne bi mogao zaboraviti vašu knjižaru i bit ću vam mnogo zahvalan, i nadam se da dobijete još novih naručitelja kako mi je već to poznato na našem brodu“ 69

Knjižari su narudžbe uputili vojnici stacionirani na ratnim brodovima, u vojnim bazama duž jadranske obale, kopnenim bazama, ali i ranjenici smješteni u vojnim bolnicama. Najviše narudžbi pristiglo je iz najveće austrougarske pomorske vojne baze u Puli (48), zatim iz Herceg Novog (23), Crkvica (7), Risana (6), Šibenika (5), Zelenike (5), Boke Kotorske (3) te po jedna narudžba iz Bileće, Drvenika, Gradaca, Gruža, Knina, Komiže, Konjevrata, Neuma, Nytre (Slovačka), Podgore, Tivata, Trebinja i Zlarina (S1. 3). ${ }^{70}$

Ranjenici koji su knjižari uputili narudžbe bili su smješteni u bolnicama ili su se oporavljali u Puli, Šibeniku, Herceg Novom, Boki Kotorskoj, Risanu, Gružu i Nyitri što su navodili u svojim narudžbama, primjerice: „KuK Reservespital“, 71 „KuK Marinespital Kommando“,72 „Rekonvaleszenten“"73 „KuK Festungspital " ${ }^{\text {" }}$ i sl. Većina brodova na kojima su vojnici bili stacionirani bili su bojni brodovi, a više narudžbi zaprimljeno je od vojnika s broda SMS Radetzky(9), zatim SMS Gamma

66 Narudžbe vojnika sadržavaju ime i prezime naručitelja, mjesto, datum, ime broda ili drugog stacionara, naslove i količinu naručenih publikacija, u rijetkim slučajevima i vojni čin ili neku opasku vezanu uz samu narudžbu.

67 N. Topić, Knjižara Morpurgo u Splitu, 181. Hrvatska - Državni arhiv u Splitu, Split (dalje: HRDAST), fond 94, MOR. 10/V (1914.-1915.) i 11/III (1916.).

68 SMS - SeinerMajestätSchiff, u prijevodu znači Brod Njegovog Veličanstva, po uzoru na britanski naziv HMS - His/HerMajestyShip. D. Pet ković, Ratna mornarica Austro-Ugarske Monarhije, 7.

69 Narudžba Lovre Školjareva iz Herceg Novog, iz 1915. godine, HR-DAST-94 MOR. 10/V.; N. Topić, Knjižara Morpurgo u Splitu, 184.

70 Za tri narudžbenice nije bilo moguće utvrditi odakle su pristigle.

71 Narudžba Rudolfa Tillicha iz Nyitre (Slovačka) od 18. srpnja 1916. godine, HR-DAST-94 MOR. $11 /$ III.

72 Narudžba Zvonimira Filippija iz Pule od 15. svibnja 1916. godine, HR-DAST-94 MOR. 11/III.

73 Narudžba Ivana Kurtovića iz Gruža od 23. ožujka 1915. godine, HR-DAST-94 MOR. 10/V.

74 Narudžbe Ive Ivčevića iz Risana od 1. i 14. listopada 1915. godine te narudžba Nike Miličevića iz Risana od 9. studenog 1915. godine. HR-DAST-94 MOR. 10/V. 


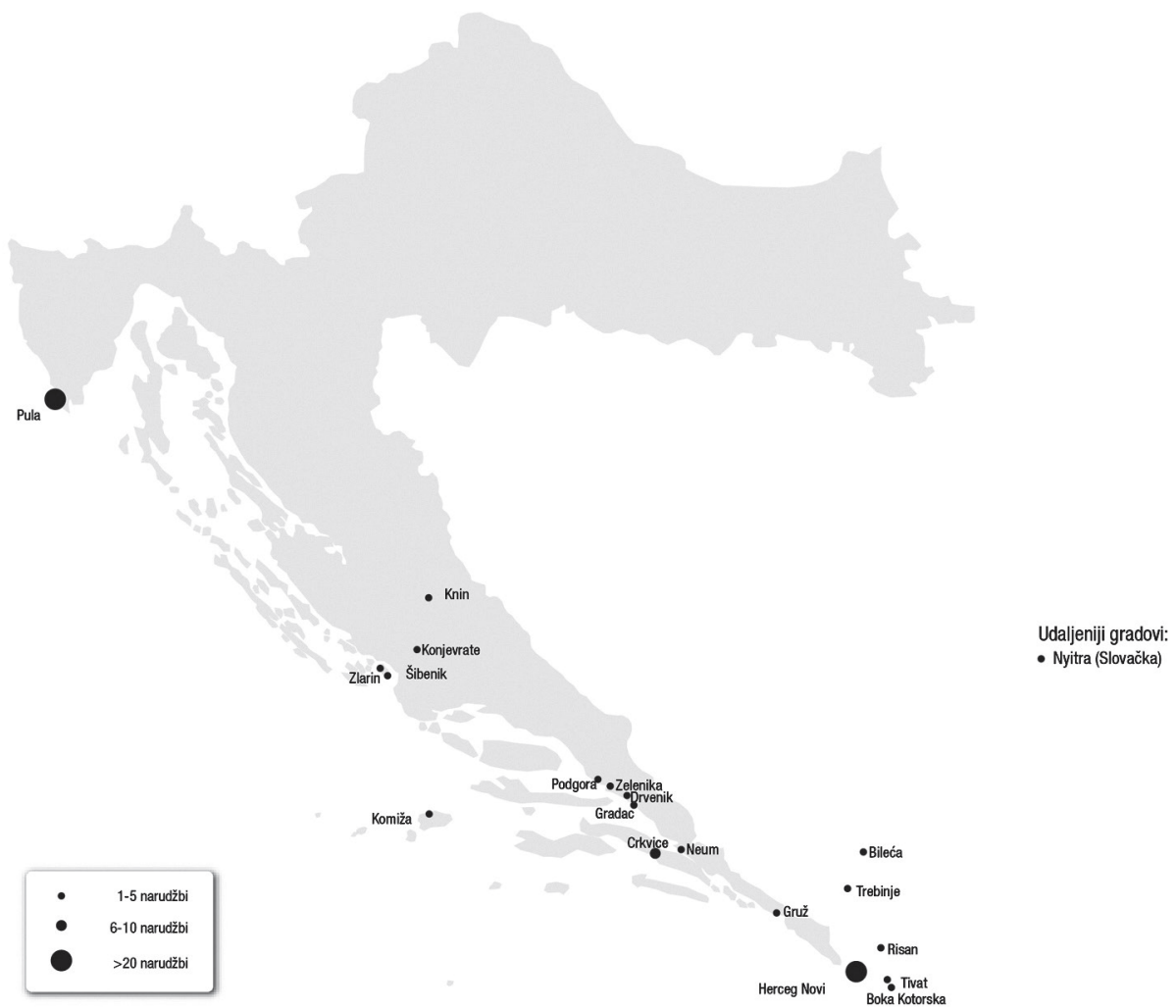

KARTA 1. Geografska rasprostranjenost kupaca (izradio: Mladen Masar)

(6), SMS Wien (5), SMS Budapest (5), SMS Leopard (4), SMS Kronprinz Erzherzog Rudolf (4), SMS Zrinyi (3), SMS Szigetvar (3), SMS Stefanie (3), SMS Erzherzog Ferdinand Max (3), SMS Kaiesr Karl VI (2), SMS Gäa (2), SMS Boot 33 (2) i SMS Franz Ferdinand (2). Po jedna narudžba pristigla je od naručitelja sa sljedećih brodova: SMS Kaiser Max, SMS Szent Istvan, SMS Sankt Georg, SMS Kaiser Franz Joseph I, SMS Boot 74, SMS Babenberg, SMS Salamander (Sl. 3), SMS Panther, SMS Minerva, SMS Lussin, SMS Lika, SMS Delta (Minerva) i SMS Dalmat. ${ }^{75}$

75 Više o vrstama i karakteristikama brodova austrougarske mornarice vidjeti u D. PET Ković, Ratna mornarica Austro-Ugarske Monarhije i Z. FreIvogel, Austrougarska vojska u Prvome svjetskom ratu. 


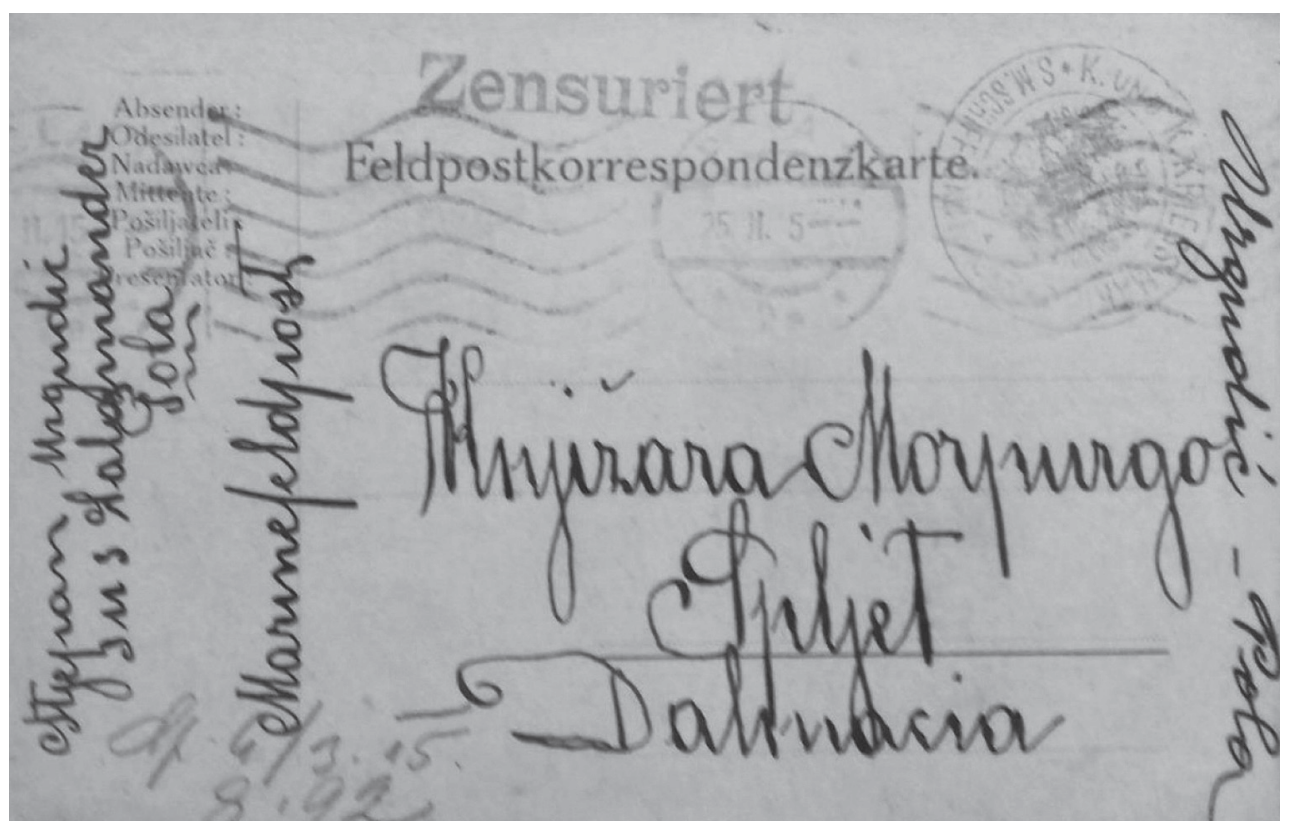

SLI KA 3. Dopisnica s narudžbom upućena Knjižari Morpurgo s broda SMS Salamander, 1915.

Sudeći po prezimenima i jeziku na kojem su narudžbe pisane, većina vojnika koji su naručili publikacije od Knjižare Morpurgo bili su Hrvati. Naime, austrougarska mornarica bila je višenacionalna zajednica koja je regrutirala vojnike iz svih zemalja u sastavu Monarhije, a većinu niže posade brodova te dočasnički i niži časnički kadar, kao što je već spomenuto, činili su upravo Hrvati. Neki od naručitelja su se i potpisali kao vojnici, primjerice: „vojnik“, „k. oružnik“, „k. poručnik“, „vojni telegrafist“, „komandant“ i sl. Službeni jezik na svim brodovima bio je njemački, ali govorilo se i talijanskim, hrvatskim, kao i ostalim jezicima zemalja u sastavu Austro-Ugarske. Nastao je i poseban palubni jezik, kao mješavina njemačkih, talijanskih i hrvatskih izraza, tzv. lingua di bordo, koji se dijelom zadržao čak do današnjih dana na brodovima s hrvatskom posadom. ${ }^{76}$ Vojnici s višim činom učili su uz to i engleski i francuski jezik, ${ }^{77}$ pa čak i hrvatski i talijanski. ${ }^{78}$

77 Z. Freivogel, Austrougarska vojska u Prvome svjetskom ratu, 229.

78 B. DobRIĆ, Kultura čitanja i nacionalni pokreti, 43. 
TABLICA 1. Jezična slika naručenih publikacija

\begin{tabular}{|c|c|c|}
\hline Jezik & Broj primjeraka & \% \\
\hline hrvatski & 763 & 89,44 \\
\hline talijanski & 29 & 3,39 \\
\hline njemački & 23 & 2,69 \\
\hline dvojezično & 16 & 1,87 \\
\hline neodređeno & 12 & 1,40 \\
\hline srpski & 5 & 0,58 \\
\hline francuski & 3 & 0,35 \\
\hline engleski & 2 & 0,23 \\
\hline Ukupno & 853 & 100,00 \\
\hline
\end{tabular}

Ukupno su vojnici od knjižare naručili 853 publikacije te uredski i školski pribor (bilježnice, notese, papir, pera za pisanje, olovke, notni papir). Većina kupaca, a najvjerojatnije se radilo o običnim vojnicima nižeg čina, naručila je publikacije pisane hrvatskim jezikom (89,44 \%) (Tablica 1). Talijanskim jezikom pisano je svega 3,39 \% naručenih publikacija, a riječ je o priručnicima za učenje talijanskog jezika (Talijanski učitelj za samouke, ${ }^{79}$ Slovnica i vježbenica talijanskog jezika, ${ }^{80}$ Praktični učitelj talijanskog ${ }^{81}$ ), novinama (Ancora), ${ }^{82}$ pravnim publikacijama (Principi di diritto costituzionale) $)^{83}$ i stručnim priručnicima (Manuale del regolatore e liquidatore di avarie e sinistri marittimi). ${ }^{84}$ Vojnik Giovanni Gerini iz Herceg Novog naručio je katalog i cjenik talijanskih romana i ostalih knjiga, a Rudolf Tillich iz bolnice u Nyitri zatražio je ,jednu knjigu na talijanskom jeziku, o ljubavi kako bismo zajedno s prijateljima mogli prevariti vrijeme, ne znamo što drugo osim da gnjavimo vas" ${ }^{85}$ Potonji zapis otkriva da

79 Publikaciju je naručio vojnik Jozo Sinković iz Herceg Novog (SMS Gäa) 5. srpnja 1915. godine.

80 Dva primjerka ove publikacije naručio je vojnik Jakov Grabar iz Herceg Novog 14. siječnja 1916.

81 Priručnik je naručio vojnik Lovre Školjarev iz Herceg Novog (SMS Kaiser Franz Joseph I) 29. lipnja 1915.

82 Pod naslovom L'Ancora izlazilo je više talijanskih dnevnih i tjednih novina političkog i religioznog karaktera. Čak 20 primjeraka ovih novina naručio je Marin Barić iz Pule (SMS Leopard), 3. travnja 1915. godine, vjerojatno za ostale kolege na brodu.

83 Vittorio Emanuele Orlando, Principi di diritto costituzionale, Firenze, 1912. Publikaciju je naručio vojnik računovođa Pero Gamulin iz Risana u Boki Kotorskoj 23. veljače 1915. godine.

84 Vittorio Rossetto, Manuale del regolatore e liquidatore di avarie e sinistri marittimi, Milano, 1903. Publikaciju je naručio vojnik Mato Lončarić iz Herceg Novog (SMS Budapest) 2. rujna 1915.

85 Zapis je u originalu na talijanskom jeziku: „un libro di amore in lingua italiana per poter insieme ai compagni in gannare il tempo non sapiamo altro che sicarere a voi." Narudžba Rudolfa Tillicha iz Nyitre (Slovačka) od 18. srpnja 1916. godine, HR-DAST-94 MOR. 11/III. 
je postojalo povjerenje između naručitelja i dobavljača u čiji se odabir naručitelj pouzdavao jer njemu prepušta odabir knjige i ne zna kome bi se drugom obratio. $S$ druge strane otkriva da su ranjenici čitanjem „kratili“ vrijeme te da je istu publikaciju čitalo više osoba. Sudeći po narudžbama, vojnici su naručivali publikacije na talijanskom jeziku radi edukacije (lingvistički priručnici) ili ako su poznavali talijanski jezik, radi informiranja (novine), posla (stručni priručnici) i razonode (romani, knjige ljubavnog sadržaja).

Njemačkim jezikom pisano je 2,69 \% naručenih publikacija, i to najviše onih iz područja lingvistike (Samouk njemačkog, Uputa u njemački jezik, Učitelj njemačkog jezika, Praktični učitelj njemačkog jezika). ${ }^{86}$ Vojnik Lovre Filipović iz Drvenika naručio je deset „zadaćnica početnim njemačkim pisano“, kao i „knjigu ljubavnog dopisivanja" na njemačkom jeziku (tzv. listar). ${ }^{87} \mathrm{Ne}$ iznenađuje potreba vojnika za učenjem njemačkog jezika jer je to bio, kako je spomenuto, službeni jezik austrougarske mornarice i jezik njihovih nadređenih. Naručene su i jedna pravna publikacija (Allgemeine Staatsrecht), ${ }^{88}$ jedna povijesna publikacija („Das Ende des kroatischen Nationalkoenigtums, oderwie und wanngelangten die Arpadenaufden Tron des kroatischen Koenigreichs ${ }^{89}$ i njemački katalog knjiga. ${ }^{90}$

I među dvojezičnim naručenim publikacijama (1,87 \%) prevladavale su one iz područja lingvistike (rječnici i gramatike), a tražene su bile sljedeće jezične kombinacije: njemačko-hrvatski, hrvatsko-njemački, hrvatsko-talijanski, talijansko-hrvatski, francusko-hrvatski, hrvatsko-francuski i talijanskonjemački. Udio naručenih publikacija na drugim stranim jezicima iznosi manje od $1 \%$ : srpski jezik 0,58 \%, francuski jezik 0,35\% i engleski jezik 0,23 \% dok se za 1,40\% publikacija nije moglo odrediti kojim su jezikom pisane.

86 Priručnike za učenje njemačkog jezika naručilo je više vojnika, a neki su naručeni i u više primjeraka.

87 Narudžba Lovre Filipovića iz Drvenika (Zaostrog) od 14. studenoga 1915., HR-DAST-94 MOR. $10 / \mathrm{V}$.

88 U prijevodu „Opće ustavno pravo“, bilo je više izdanja ove publikacije. Naručio vojnik računovođa Pero Gamulin iz Risana u Boki Kotorskoj 23. veljače 1915. godine.

89 Koharić, Janko, Das Ende des kroatischen Nationalkoenigtums: oderwie und wanngelangten die Arpadenaufden Tron des kroatischen Koenigreichs, Agram: Commissionsverlag der Buchhandlung G. Trpinac, 1904. Naručio vojnik Nikolaus Jeličić iz Zelenike u Boki Kotorskoj (SMS Kronprinz Erzherzog Rudolf) 12. veljače 1915. godine. Riječ je o publikaciji koja govori o hrvatskoj srednjovjekovnoj prošlosti.

90 Katalog je naručio vojnik Ivan Nešković iz Pule (SMS Kaiser Karl VI) 20. studenoga 1915. godine. 
TABLICA 2. Naručene publikacije prema vrsti/sadržaju

\begin{tabular}{|c|c|c|}
\hline $\begin{array}{c}\text { Vrsta/sadržaj } \\
\text { publikacije }\end{array}$ & Broj primjeraka & \% \\
\hline Književnost & 411 & 48,18 \\
\hline Religija & 147 & 17,23 \\
\hline Razno & 63 & 7,38 \\
\hline Drušstvene znanosti & 48 & 5,62 \\
\hline Lingvistika & 37 & 4,33 \\
\hline Serijske publikacije & 30 & 3,51 \\
\hline Primijenjene znanosti & 30 & 3,51 \\
\hline Povijest & 26 & 3,04 \\
\hline Geografija & 24 & 2,81 \\
\hline Neodređeno & 22 & 2,57 \\
\hline Prirodne znanosti & 6 & 0,70 \\
\hline Biografije & 3 & 0,35 \\
\hline Filozofija & 2 & 0,23 \\
\hline Psihologija & 2 & 0,23 \\
\hline Umjetnost i sport & 2 & 0,23 \\
\hline Ukupno & 853 & 100,00 \\
\hline
\end{tabular}

Gotovo polovica naručenih publikacija pripada području književnosti $(48,18 \%)$ (Tablica 2$)$, a posebno su bile tražene, pa vjerojatno i rado čitane, već spomenute epske pjesme koje su govorile o vojničkom životu, životu mornara i putovanjima austrougarskih brodova. Tako su primjerice u čak trideset primjeraka naručene Nove vojničke pjesme, ${ }^{91}$ a u dvadeset primjeraka Dvije pjesme: uspomena mobilizacije i svjetskog rata god. 1914-1915. ${ }^{92}$ što znači ili da su bile preprodavane ili samo naručene za više kupaca. Zatim, u više primjeraka su naručene i Hrvatska pjesmarica, Vojnička pjesmarica, Nova vojnička pjesmarica, Spomen pjesme: uspomene iz vojničkog života, Ratne pjesme i Ljubavne šaljive $i$ svatovne pjesme. Vojnici su naručivali i sljedeće pjesmarice objavljene u izdanju Knjižare Morpurgo: Pjesma putovanja Njeg. Vel. Broda Szigetvara u Kinu god. 1907. i Uzdasi za djevojkom (S1. 4), ${ }^{93}$ Andrija Šimić hajdučki harambaša,${ }^{94}$ Ljubav

91 Naručio ih je Anton Radnić iz Tivata 18. kolovoza 1915. godine.

92 Antun Kovačev, Dvije pjesme: uspomena mobilizacije i svjetskog rata god. 1914-1915, Pula, 1915. Naručio ih je Antun Šeparović iz Šibenika 15. rujna 1915. godine (Fort S. Nicolo).

93 Kajo Roje Splićanin, Pjesma putovanja Njeg. Vel. Broda Szigetvara u Kinu god. 1907. i Uzdasi za djevojkom, Split, 1913.

94 Ivan Mimica, Andrija Šimić hajdučki harambaša:pjesma u pet pjevanja. Treće popravljeno izd., Split, 1898. Ova pjesmarica izašla je u izdanju Knjižare Morpurgo i 1913. godine. 


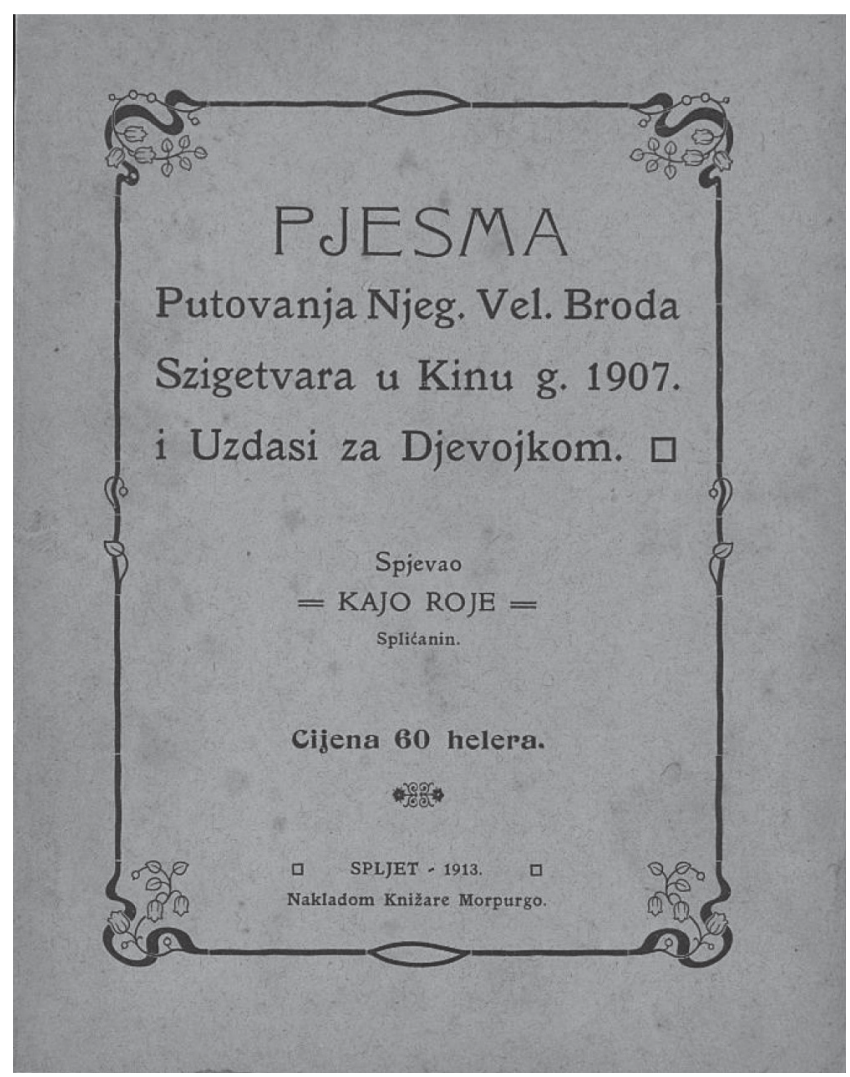

Sli Ka 4. Kajo Roje Splićanin, Pjesma Putovanja Njeg. Vel. Broda Szigetvara u Kinu g. 1907. i Uzdasi za Djevojkom, Split, 1913.

Paške Baranovića sa Zorkom Julović-Škarica, ${ }^{95}$ Muka Gospodina našega Isukrsta i Plač Matere njegove ${ }^{96}$ i Josip Pravedni: to jest skazanje kako sinovi Jakova Patriarke prodaše Jozipa. ${ }^{97}$ Vojni komandant koji se potpisao kao M. Marušić ${ }^{98}$ naručio je Izabrane pjesme Silvija Strahimira Kranjčevića, ${ }^{99}$ Pobrane pjesme

95 Ivan MiletA, Ljubav Paške Baranovića sa Zorkom Julović-Škarica, njezina tragična smrt pak njegova rasprava, tamnovanje i smrt. 2 pomnoženo i popravlj. izd., Split, <s.a.>

96 Petar Knežević, Muka Gospodina našega Isukrsta i Plač Matere njegove. Dvadeset i peto izdanje, Split, 1908.

97 Petar Vuletić, Josip Pravedni: to jest skazanje kako sinovi Jakova Patriarke prodaše Jozipa brata svoga izmaelićanom. Dvadeseto izdanje, Split, 1911.

98 Narudžba M. Marušića iz Boke Kotorske od 31. kolovoza 1915. godine koji se potpisao kao komandant broda SMS Dalmat.

99 Bilo je više izdanja Kranjčevićevih pjesama u ovom periodu. Primjerice: Silvije Strahimir KranJČEvić, Život i probrane pjesme, Koprivnica, 1921. 
Petra Preradovića ${ }^{100}$ i Izabrane pjesme Augusta Šenoe, a vojnik Toma Tabulov ${ }^{101}$ dva Danteova djela, Pakao i Divna gluma. ${ }^{102}$ Čitanje pjesmarica međutim nije bila specifičnost samo vojnika austrougarske mornarice. Tako su primjerice i britanski vojnici u ratnoj posudbenoj knjižnici u Arrasu (Francuska), često posuđivali zbirke poezije, ponajprije zbog njihove fragmentarnosti i činjenice da su ih mogli lako čitati u diskontinuitetu, kada god bi im vrijeme i mogućnosti to dopuštale. ${ }^{103}$

Osim pjesmarica, vojnici su naručili i veći broj romana i pripovijetki (187). U najvećem broju primjeraka naručena je pripovijetka Genoveva Christopha von Schmida (10), ${ }^{104}$ zatim romani Urota zrinsko-frankopanska Eugena Kumičića (5), ${ }^{105}$ Miljenko i Dobrila Marka Kažotića (4), ${ }^{106}$ Nenadani susret: roman iz mornarskoga života Charka Russela $(4)^{107}$ i Krvava ruka Xaviera de Montépina (4). ${ }^{108} \mathrm{Uz}$ romane povijesne tematike, poput onih Eugena Kumičića (Urota zrinsko-frankopanska, ${ }^{109}$ Kraljica Lepa ${ }^{110}$ ) i Henryka Sienkiewicza (Quo vadis?), ${ }^{11}$ traženi su bili i ljubavni romani i pripovijetke (Miljenko i Dobrila, ${ }^{112}$ Ljubav $i$ izdaja $^{113}$ ), kao i oni kriminalističkog (Gdje je milijunar, ${ }^{114}$ Zatajena ženidba, ${ }^{115}$ Tajna žute sobe $e^{116}$ ), odnosno fantastičnog ili horor sadržaja (Umorstva u ulici

100 Petar Preradović, Izabrane pjesme, Zagreb, 1890.

101 Narudžba Tome Tabulova iz Zelenike (SMS Kronprinz Erzherzog Rudolf) od 13. srpnja 1916. godine.

102 Riječ je o prijevodu Danteove Božanstvene komedije objavljene pod tim naslovom. Dante Alighieri, Divna gluma, Kotor, 1910.

103 E. G. C. KING, E. W. Hornung’s Unpublished „Diary“, 376.

104 Christoph von Schmid, Genoveva: pripovijest iz starine za matere i djecu, Zagreb, 1909.

105 Knjižara „L. Hartman“ iz Zagreba objavila je više izdanja ovog romana početkom 20. stoljeća.

106 Marko Kažotić, Miljenko i Dobrila, Zagreb, 1903., (Hrvatska biblioteka, sv. 63-65).

107 Chark Russel, Nenadani susret: roman iz mornarskoga života, Zagreb, 1904., (Hrvatska biblioteka, sv. 372-374).

108 Xavier de MontePin, Krvava ruka (Crvena krabulja), Zagreb, 1902., (Hrvatska biblioteka, sv. 302311). Osim navedenog, naručivani su i drugi romani i pripovijetke ovoga autora: Čovjek s voštanim kipovima, Maćje oko i Tajanstveni ubojica.

109 Eugen Kumičıć, Urota Zrinsko-Frankopanska, Zagreb, 1894. Bilo je više izdanja ovog romana.

110 Eugen Kumičić, Kraljica Lepa, Zagreb, 1906., (Hrvatska biblioteka, sv. 331-333).

11 Henryk Sienkiewicz, Quo vadis?: historički roman iz doba cara Nerona, Zagreb, 1912., (Hrvatska biblioteka, sv. 588-593).

112 Marko Kažotić, Miljenko i Dobrila.

113 Auguste MAQUET, Ljubav i izdaja, Zagreb, ? (Hrvatska biblioteka, sv. 244-246).

114 Eugen Chavetте, Gdje je milijunar?: kriminalni roman, Zagreb, ?

115 Anna Katherine GreEn, Zatajena ženidba: kriminalni roman, Zagreb, ? (Hrvatska biblioteka, sv. 781-784).

116 Gaston Leroux, Tajna žute sobe: kriminalni roman, Zagreb, ? (Hrvatska biblioteka, sv. 751-754). 
Morgue ${ }^{117}$ Uspomene živog pokopanog $\left.{ }^{118}\right)$. Pojedinačno su naručena i djela drugih autora: Emila Zole (Slom), ${ }^{119}$ Honorea de Balzaca (Kobna klisura), ${ }^{120}$ Lava Nikolajeviča Tolstoja (Gospodar $i$ sluga), ${ }^{121}$ Alessandra Manzonija (Vjerenici), ${ }^{122}$ Augusta Šenoe (Zlatarevo zlato) ${ }^{123}$ itd. Većina naručenih romana i pripovijetki izlazila je u sveščićima kao dio Hrvatske biblioteke knjižare „L. Hartman“ iz Zagreba i prodavala se po vrlo pristupačnim cijenama. Ponekad su vojnici prepuštali izbor publikacije knjižaru, pa tako stanoviti Marko Glavina uz svoju narudžbu piše: „U slučaju da imate još koji zanimivi Kriminalni romana izvolite priložiti i to da ukupan iznos bude iznosio 10-12 K“. ${ }^{124}$ Romani su inače bili prvi izbor vojnika na gotovo svim europskim bojišnicama, a posebno se to ticalo ljubavnih i kriminalističkih romana, koji su ih odvraćali od ružne svakodnevice u kojoj su živjeli. ${ }^{125}$

U većem broju primjeraka naručeni su društveno angažirani eseji Lava Nikolajeviča Tolstoja (Ne mogu šutjeti, Mora li zbilja tako biti?, Na ljudskoj klaonici, Veliki socialni grieh, Konac jednog vieka itd.) ${ }^{126}$ te listari (zbirke ljubavnih i drugih pisama) koji su vojnicima vjerojatno služili kao predložak za pisanje pisama. Ostali naslovi iz područja književnosti naručivani su u mnogo manjem broju primjeraka, primjerice naručeno je svega sedam dramskih djela, osam poligrafija, pet primjeraka djela iz područja retorike, dva putopisa itd.

Zanimljivo je da su pripadnici austrougarske vojske naručivali i dječje publikacije, od slikovnica, priča i basni do molitvenika i udžbenika, vjerojatno ne za sebe nego za mlađe članove svojih obitelji. Naručene su tako slikovnice

117 Edgar Allan PoE, Zagonetna umorstva u ulici Morgue: pripoviest, Zagreb, ? (Hrvatska biblioteka, sv. 72).

118 H. Smith, Uspomene živog zakopanog, Zagreb, ? (Hrvatska biblioteka, sv. 236).

119 Emile Zola, Slom, Zagreb, 1915.

120 Honore de BAlzac, Kobna klisura, Zagreb, 1905. (Hrvatska biblioteka, 417-419).

121 Lav Nikolaevič TolstoJ, Gospodar i sluga, Zagreb, 1908. (Hrvatska biblioteka, sv. 150-151).

122 Alessandro MAnzoni, Vjerenici: historična pripovijest milaneska iz XVII, Split, 1897. Ovaj roman kod nas je poznatiji pod naslovom Zaručnici.

123 August ŠEnOA, Zlatarovo zlato: historička pripoviest XVII. vieka, Zagreb, 1910.

124 Narudžba Marka Glavine iz Crkvica (K.K. Landsturm II/37) iz 1915. godine, HR-DAST-94 MOR. $10 / \mathrm{V}$.

125 E. G. C. KIng, Books Are More to Me Than Food, 260. King navodi da su primjerice u posudbenoj knjižnici u Arrasu čak $87 \%$ posuđenih knjiga bili romani. E. G. C. KInG, E. W. Hornung's Unpublished „Diary“, 373; A. LAugesen, Finding „Another Great World“, 434; Uz njih, navodi Souers, vrlo su popularne bile i biografije, vesterni i putopisi. K. L. SouERs, The Library and the Community it Serves in Times of War, 17.

126 Tolstojevi eseji u hrvatskom su prijevodu izlazili u izdanju knjižare S. Juenkera (Sisak) i knjižare L. Hartman (Zagreb) krajem 19. i početkom 20. stoljeća. 
Pepeljuga, ${ }^{127}$ Snjeguljica, ${ }^{128}$ Ivo i Marica, ${ }^{129} 150$ priča za mladež Franza Hoffmana, ${ }^{130}$ Najljepši ures duši i srcu dobre hrvačadi: čudoredno-poučne priče i pripovijesti za mladež Ivana Tomašića, ${ }^{131}$ Isus prijatelj malenih, ${ }^{132}$ Basne, ${ }^{133}$ Ilustrovani prirodopis životinjstva, bilinstva $i$ rudarstva za mladež sa 300 bojadisanih $i$ osamdeset $i$ pet cernih slika ${ }^{134}$ itd. I već spomenuta pripovijetka Genoveva ${ }^{135}$ Christopha von Schmida može se smatrati dječjom knjigom koja je bila očito rado čitana i kod odrasle čitateljske publike. Sva naručena dječja literatura bila je poučnog karaktera, što je i bilo glavno obilježje literature namijenjene djeci tijekom 19. stoljeća, a zadržalo se i u prvoj polovici 20. stoljeća.

Značajan udio među naručenim publikacijama imaju one religioznog karaktera: molitvenici, hagiografije, katekizmi, pjesmarice, oficiji, Biblija itd. (17,23 \%). Najtraženija je bila knjižica koja sadrži pučku pobožnost Blaženoj Djevici Mariji i Isusu Kristu pod nazivom San Blažene Djevice Marije koja je naručena čak u 48 primjeraka. Stanoviti Ivan Kurtović, ranjenik koji je boravio u vojnoj bolnici u Gružu, naručio je 15 primjeraka ove knjižice napisavši: „Veleštovani gospodine nas mnoštvo se je uvjerilo u ovu knjižicu san blažene djevice marije čuli smo da vi imate u vašoj knjižari izvolte nam javiti imateli i cijenu najnižu poduzećem poštanskog ureda pošaljite komada 15 ako mi ne vjerujete obratite se kod gosp. Dujma Savo on će vam objasniti o meni sa štovanjem“. 136

127 Slikovnicu je naručio vojnik Antun Miculinić iz Pule (SMS Delta Minerva) 5. travnja 1915. godine.

128 Isto.

129 Slikovnicu je naručio vojnik Petar Ostojić iz Pule (SMS Radetzky) 10. rujna 1915. godine.

130 Bilo je više različitih izdanja Hoffmannovih pripovijetki, ali pod ovim naslovom nije pronađena ni jedna publikacija. Međutim, u izdanju knjižare „Lav. Hartman“ objavljivane su Hoffmannove pripovijetke (Franz Hoffman, Franje Hofmana četrdeset i dvije pripovijetke za mladež, Zagreb, poslije 1900.). Naručio ih je Mate Antunović iz Crkvica 1. studenoga 1915. godine.

131 Ivan Tomašıć, Najljepši ures duši i srcu dobre hrvačadi: čudoredno-poučne priče i pripovijesti za mladež, Zagreb, 1897. Naručio ih je Josip Mogaš iz Pule (SMS Boot 33) 7. rujna 1915. godine.

132 Aegidius JAIs, Isus prijatelj malenih ili pustite $k$ meni malene: molitvena knjižica s katekizmom $i$ pjesmama za djevojke, Zagreb, 1914. Ovaj molitvenik naručilo je više kupaca.

133 Basne je naručio vojnik Antun Miculinić iz Pule (SMS Delta Minerva) 5. travnja 1915. godine.

134 Ovaj udžbenik naručilo je više kupaca: Nino Pandol iz Pule (SMS Leopard) 28. listopada 1915., Marin Barić iz Pule (SMS Leopard) 2. studenoga 1915. i Petar Ostojić iz Pule (SMS Radetzky) 10. rujna 1915 . godine.

135 Prema Berislavu Majhutu i Sanji Lovrić, pripovijetka Genoveva, uz Defoeva Robinsona, „ispunjava najveći dio hrvatskoga književnoga prostora namijenjenoga djeci sve do sredine 19. st. Iako prve verzije priče o Genovevi nisu namijenjene isključivo djeci, one su korijeni priče koja će trajno obilježiti hrvatsku dječju književnost“. Berislav Majhut, Sanja Lovrić, Središnji motiv Genoveve i njegove reinkarnacije u hrvatskoj dječjoj književnosti, Kroatologija, sv. 1, Zagreb, 2010., 153. Očito se popularnost ove pripovijetke kod hrvatskih čitatelja zadržala i u prvim desetljećima 20. stoljeća. N. Topić, Uloga splitske knjižare Morpurgo, 165.

136 Narudžba Ivana Kurtovića iz Gruža od 23. ožujka 1915. godine, HR-DAST-94 MOR. 10/V. 
Vojnik Mate Vuković naručio je 10 primjeraka ove publikacije, ${ }^{137}$ kao i vojnik Teodor Matiazzi, ${ }^{138}$ a bilo je i drugih pojedinačnih narudžbi, što svjedoči da je ova publikacija bila izrazito tražena i popularna među vojnicima koji su u njoj vjerojatno pronalazili utjehu i ohrabrenje u teškim životnim prilikama. Od drugih religioznih publikacija u više primjeraka naručena je i zbirka molitvi Kita dubovnoga cvieća (29), ${ }^{139}$ kao i različite hagiografije (10). ${ }^{140}$ Pojedini kupci tražili su i bolji uvez („fino vezani“) molitvenika koje su naručivali, pa čak i onaj od bjelokosti, što znači da su iznimno cijenili ove publikacije. ${ }^{141}$ Samo jedna naručena publikacija iz područja religije sadržajno pripada pravoslavnoj vjeroispovijesti, ${ }^{142}$ dok su sve ostale rimokatoličke, što ne iznenađuje jer su na području Dalmacije na prijelazu iz 19. u 20. stoljeće rimokatolici činili većinu stanovništva $(83,69 \%) .{ }^{143}$ Vjerska je literatura inače bila dijelom čitateljskih interesa vojnika diljem Europe i šire. Tako Amanda Laugesen navodi, pišući o knjižnicama i čitateljskim navikama australskih vojnika u Prvom svjetskom ratu, da je udruga The Young Men's Christian Association (YMCA) vojnicima nudila vjersku literaturu, ali i za njih organizirala mise i katehezu, što je mnogima u ratnim vremenima predstavljalo veliku utjehu i donosilo duhovni mir. ${ }^{144}$

Vojnici su naručili i veći broj kataloga knjiga, cjenika i raznih brošura, posebno onih vezanih uz gatanje te bračni i ljubavni život (7,38\%). Naručene su tako sljedeće publikacije: Ljubavni prorok za gospodje koji na više pitanja odgovara, ${ }^{145}$ Gatanja stare ciganke sa dvije kocke, ${ }^{146}$ Čaranje i vračanje, ${ }^{147}$ a Šime Franov iz Pule je primjerice tražio „najveći sanovnik“. ${ }^{148}$ Zanimljivo je da su vojnici koji su naručili publikacije ovog sadržaja nerijetko naručivali i molitvenike i druge publikacije religioznog sadržaja pa se njihov odabir publikacija može povezati ne samo s religioznošću

137 Narudžba Mate Vukovića (SMS Babenberg) od 26. veljače 1915. godine.

138 Narudžba Teodora Matiazzija iz Crkvica od 20. rujna 1915. godine.

139 Alfonso Ligorije, Kita duhovnoga cvieća: istine vikovične Alfonsa Ligorija i različite molitve, Zadar, 1891. Tiskano s dopuštenjem Nadbiskupskoga naredbeništva.

140 Život svetaca i svetica božjih, Život sv. Katarine, Život sv. Roka, Herojstvo Sv. Dujma mučenika i prvog solinskog biskupa, Sv. Nikola, Život sv. Antuna od Padove itd.

141 Vjekoslav Brok iz Pule (SMS Szigetvar) tražio je 1915. godine molitvenik Isus prijatelj mladih, i to „vezan u bijeloj kosti“, Narudžba Vjekoslava Broka iz 1915. godine, HR-DAST-94 MOR. 10/V.

142 Grčko-istočni katekizam naručio je Peter Beara iz Trebinja 6. kolovoza 1915. godine.

143 Prema vjeroispovijesti pravoslavnog stanovništva bilo je 16,22 \%, a ostalih 0,09\% (protestanata, Židova). Ivo Juras, Pregled gospodarstva i trgovine u Dalmaciji, Zadar, 1910., 12 - 13.

144 A. Laugesen, Finding „Another Great World“, 423.

145 Narudžba Andrije Vlahova iz Pule (SMS Minerva) od 22. veljače 1915. godine.

146 Narudžba Tomislava Gulama iz Šibenika od 20. rujna 1915. godine.

147 Narudžba Ivana Vrsaljka iz Boke Kotorske (SMS Wien) od 19. ožujka 1915. godine.

148 Narudžba Šime Franova iz Pule (SMS Stefanie) od 23. listopada 1915. godine. 
nego i praznovjernošću. Tražene su i brošure sa sadržajima vezanim uz bračni život i ljubavne odnose, primjerice Kako ćete uspjeti kod žena, ${ }^{149}$ Bračna pravila i pouke, ${ }^{150}$ Kratak nauk o ženidbi, ${ }^{151}$ Sreća kod žena, naputak za mlade muškarce. ${ }^{152}$ Vojnici koji su naručivali ove publikacije u narudžbenicama navode ponekad i ljubavne romane i pripovijetke što znači da su ih privlačili i okupirali sentimentalni sadržaji. Naručeno je i nekoliko brošura vezanih uz vojnički život $O$ vojničkoj poslušnosti, ${ }^{153}$ Vojnički priručnik ${ }^{154}$ i Vojničke šale i dosjetke iz njemačke vojske. ${ }^{155}$

U području društvenih znanosti (5,62 \%) među naručenim publikacijama najzastupljenije su one pedagoškog sadržaja, i to udžbenici iz različitih predmeta (aritmetika, geometrija, prirodopis). Naručeno je i deset „zadaćnica početnim njemačkim pisano " ${ }^{156}$ te dvije Abecedarke za poučavanje odraslih nepismenih, ${ }^{157}$ što znači da je među vojnicima bilo i nepismenih osoba, kao i onih koji su u vojsci učili njemački jezik koji je, kako je već spomenuto, bio službeni jezik austrougarske vojske. Nepismenog stanovništva u Dalmaciji je tada bilo oko $78 \%,{ }^{158}$ što je velik postotak. Vrijeme je to kada dolazi do organiziranog opismenjavanja odraslih održavanjem analfabetskih tečajeva u svim dijelovima Hrvatske što je pridonijelo porastu broja pismenog stanovništva, pa tako i čitatelja. ${ }^{159}$ Vojnici su naručili i devet pravnih publikacija (primjerice, Austrijsko bračno ženidbeno i udajno pravo, ${ }^{160}$ Opći austrijski građanski zakon, ${ }^{161}$ Pučki pravnik $i$ obiteljsko pravo, ${ }^{162}$ Zavičajno pravo $^{163}$ itd.), četiri publikacije vezane za lijepo ponašanje (primjerice, O pristojnom vladanju u svim životnim prilikama Marije Jambrišak), ${ }^{164}$ i svega

149 Narudžba Daneka Lada iz Komiže na Visu od 12. ožujka 1915. godine.

150 Narudžba Petra Ostojića iz Pule (SMS Radetzky) od 10. rujna 1915. godine.

151 Narudžba Lovre Školjareva iz Herceg Novog (SMS Kaiser Franz Joseph I) od 29. lipnja 1915.

152 Narudžba Marijana Belaja iz Pule (SMS Stefanie) od 17. kolovoza 1915. godine.

153 Narudžba Antuna Miculinića iz Pule (SMS Delta Minerva) 5. travnja 1915. godine

154 Narudžba Pere Klarića iz Neuma od 25. rujna 1915. godine.

155 Narudžba Mate Antunovića iz Crkvica iz 1915. godine.

156 Zadaćnice je naručio Lovre Filipović iz Drvenika (Zaostrog) 14. studenoga 1915. godine, HRDAST-94 MOR. 10/V.

157 Antun Peulić, Abecedarka za poučavanje odraslib nepismenih, Zagreb, 1911. Naručio ju je vojnik Ivan Vrsaljko iz Boke Kotorske (SMS Wien) 19. ožujka 1915. godine.

158 I. Juras, Pregled gospodarstva i trgovine u Dalmaciji, 12 - 13.

159 Branka Uja Ković, $A B C$ za odrasle: opismenjavanje odraslib u 20. stoljeću, Zagreb, 2005., 20 - 21.

160 Narudžba Stjepana Gulića, „oružnika“ iz Gradaca kod Makarske iz 1916. godine.

161 Narudžba Kuzmana Devića, „oružnika“ iz Konjevrata kod Šibenika iz 1915. godine.

162 Narudžba Jakova Grabara iz Herceg Novog od 10. srpnja 1916. godine.

163 Narudžba Jakova Grabara iz Herceg Novog od 10. srpnja 1916. godine.

164 Marija JAMBRIŠAK, O pristojnom vladanju u svim životnim prilikama: rukovod za općenje u obitelji $i$ u društvu i u javnom životu, Zagreb, 1907. Naručili su vojnici Marin Barić iz Pule (SMS Leopard) 2. studenoga 1915. godine i Stefan Gulić, „oružnik“iz Gradaca kod Makarske 1916. godine. 
dvije publikacije političkog sadržaja (Pariška komuna i ideja države, ${ }^{165}$ Albanski problemi i Srbija i Austro-Ugarska $\left.{ }^{166}\right)$. Izostanak publikacija političkog sadržaja može se protumačiti činjenicom da su naručitelji radili i živjeli u okruženju koje je imalo strogu strukturu i bilo pod budnim nadzorom vlasti. Publikacije iz svih ostalih područja naručene su u udjelu manjem od 5,00 \%.

Iz područja lingvistike bili su traženi rječnici, gramatike i priručnici za učenje stranih jezika (talijanskog, njemačkog, francuskog). Od serijskih publikacija, među vojnicima je bio osobito tražen Stoljetni kalendar, a riječ je o publikaciji koja je sadržavala različite tekstove vezane za tumačenje vremenskih pojava, proricanje, meteorologiju i sl. Vojnici su naručivali i publikacije iz područja primijenjenih znanosti, posebno iz medicine (primjerice, Kućni liečnik, ${ }^{167}$ Spolne bolesti, ${ }^{168}$ Domaća ljekarna, ${ }^{169}$ Tuberkuloza,${ }^{170}$ ) i poljoprivrede (primjerice, Uputa za pravljenje vina, ${ }^{171}$ Sadimo amerikansku lozu! ${ }^{172}$ Bolesti trsa $i$ vinove loze $\left.{ }^{173}\right)$. Budući da su naručitelji bili većinom vojnici nižeg čina, može se pretpostaviti da su vojačeni iz redova težaka koji su se bavili zemljoradnjom, i to na području Dalmacije u kojoj je vinova loza, uz maslinarstvo, bila najvažnija poljoprivredna kultura. Od povijesnih publikacija, vojnici su naručivali publikacije vezane uz hrvatsku prošlost (Povijest Hrvata, ${ }^{174}$ Hrvatska povijest od najstarijih do

165 Mihail Bakunin, Pariška komuna i ideja države, Sarajevo, 1913. Naručio ju je vojnik Petar Ostojić iz Pule (SMS Radetzky) 10. rujna 1915.

166 Stjepan Protić, Albanski problemi i Srbija i Austro-Ugarska, Beograd, 1913. Publikacija je objavljena pod pseudonimom Balkanicus, a naručio ju je Nikolaus Jeličić iz Boke Kotorske (SMS Kronprinz Erzherzog Rudolf) 12. veljače 1915. godine.

167 Antun Lobmayer, Kućni liećnik: popularno zdravoslovje za svakoga: sa 153 slike u tekstu $i 1$ bojadisanom „čovječje tielo“, Zagreb, 1900. Ovu publikaciju naručila su trojica vojnika: Ante Antulov iz Pule 1914. godine, Ante Vuleta iz bolnice u Herceg Novom 25. travnja 1915. godine i Mate Ercegović (SMS Radetzky) iz Pule 4. siječnja 1916. godine

168 Petar KrIšToF, Spolne bolesti: iskusni i praktični savjeti za spolne bolesti, Zagreb, 19?? Publikaciju je naručio vojni komandant M. Marušić (SMS Dalmat) iz Boke Kotorske 31. kolovoza 1915. godine.

169 Škender HoRvat, Domaća ljekarna: po uputi župnika Sebastijana Kneippa, Zagreb, 1898. Narudžba Ivana Vrsaljka (SMS Wien) iz Boke Kotorske od 19. ožujka 1915. godine.

170 Luka KARAmAn, Tuberkuloza: (sušica, sučija, jektika): šta je, kako se suzbija i liječi: sa 27 slika, Sarajevo, 1912. Naručio ju je Toma Tabulov (SMS Kronprinz Erzherzog Rudolf) iz Zelenike 13. srpnja 1916. godine.

171 Publikaciju je naručio Antun Šeparović iz Šibenika 15. rujna 1915. godine (Fort S. Nicolo).

172 Stanko OžAnić, Sadimo amerikansku lozu!, Split, 1904. Naručio ju je Toma Tabulov (SMS Kronprinz Erzherzog Rudolf) iz Zelenike 13. srpnja 1916. godine.

173 Ivan Radić, Bolesti trsa i vinove loze, Zagreb, 1908. Naručio ju je Toma Tabulov (SMS Kronprinz Erzherzog Rudolf) iz Zelenike 13. srpnja 1916. godine.

174 Vjekoslav Klaić, Povijest Hrvata, Zagreb, 1898. Dva sveska ove publikacije naručio je Perica Pam (SMS Gamma) iz Pule 22. ožujka 1916. godine. 
najnovijih vremena, ${ }^{175}$ Hrvati i Hrvatska pod Napoleonom Velikim, ${ }^{176}$ Mala povjest Hrvata $^{177}$ ), povijest Austro-Ugarske (Povijest Austro-Ugarske Monarbije), ${ }^{178}$ povijest Srbije (Stara Srbija sa istorijsko jezičke strane) ${ }^{179}$ i rimsku povijest (Tita Livija Povijesti rimske). ${ }^{180}$ Naručivali su i geografske karte, atlase te geografske prikaze uglavnom Austro-Ugarske Monarhije od kojih su neki bili udžbeničkog karaktera (Ratna karta Balkana, ${ }^{181}$ Zemljopis austrijsko-ugarske monarkije, ${ }^{182}$ Atlas Austro-Ugarske Monarbije, $\left.{ }^{183}\right)$. U području prirodnih znanosti naručen je jedan računar (tablica s brzim izračunavanjem kubika) te nekoliko publikacija iz područja fizike, odnosno astronomije (Crtice o magnetizmu i elektricitetu, ${ }^{184}$ Naše nebo: crtice iz astronomije $e^{185}$ ). Iako su biografije tijekom 19. stoljeća bile rado čitan literarni žanr, naručene su svega tri, a sve ih je naručio stanoviti Nikolaus Jeličić 1915. godine: Život Petra Velikoga cara Rusije, ${ }^{186}$ Crtice iz života našega kralja Franje Josipa II. ${ }^{187}$ i Ban Jelačić: hrvatski narodni junak. ${ }^{188} \mathrm{U}$ dva

175 Ferdo Šıšić, Hrvatska povijest, Zagreb, 1906 - 1913. Naručio ju je Lovre Školjarev iz Herceg Novog (SMS Kaiser Franz Joseph I) 29. lipnja 1915.

176 Ivan Devčić, Hrvati i Hrvatska pod Napoleonom Velikim: ukrašeno sa četrnaest slika, Zagreb, 1900. Naručio je Grgo Bjeliš (SMS Zrinyi) iz Pule 21. ožujka 1915. godine.

177 Ivan BoJničić, Mala povijest Hrvata, Zagreb, 1908. Ovu publikaciju naručio je Ivan Pilirata (SMS Gamma) iz Pule 19. listopada 1915. godine.

178 Vjekoslav KLAIć, Povijest Austro-Ugarske Monarhije. Bilo je više izdanja ove publikacije, a vjerojatno je riječ o udžbeniku. Naručio ju je Lovre Školjarev iz Herceg Novog (SMS Kaiser Franz Joseph I) 29. lipnja 1915.

179 Bilo je više publikacija s naslovom Stara Srbija tako da nije jasno o kojem je izdanju riječ. Naručio ju je Petar Ostojić (SMS Radetzky) iz Pule 10. rujna 1915. godine.

180 Titus Livius, Tita Livija Povijesti rimske od sazdanja grada, Varaždin, 1906. Naručio ju je Toma Tabulov (SMS Kronprinz Erzherzog Rudolf) iz Zelenike 13. srpnja 1916. godine.

181 Kartu je naručio vojnik prezimena Košević iz Bileće 17. studenoga 1915. godine.

182 Ivan HoIć, Zemljopis austrijsko-ugarske monarkije za gradjanske škole, Zagreb, 1882. Naručio vojnik prezimena Košević iz Bileće 17. studenoga 1915. godine.

183 Atlas je naručio Nikola Lisac (SMS Wien) iz Herceg Novog 3. travnja 1915. godine.

184 Oton Kučera, Crtice o magnetizmu i elektricitetu, Zagreb, 1891. Naručio Stjepan Turina (SMS Erzherzog Ferdinand Max) iz Pule 6. svibnja 1916.

185 Oton KučEra, Naše nebo: crtice iz astronomije, Zagreb, 1895. Naručio Ivan Pilirata (SMS Gamma) iz Pule 19. listopada 1915. godine.

186 Riječ je vjerojatno o sljedećoj publikaciji koja je imala više prerada i izdanja: Život Petra Velikoga cara Rusije izpisan od Arkimandrite Antonie Katifora; a preveden u jezik hrvatski s malim nadodanjem od Aleksandra Tomikovicha; na novo ga izdaje Ivan pl. Mař̌so Maršovski, Budimpešta, 1876. Naručio ju je Nikolaus Jeličić (SMS Kronprinz Erzherzog Rudolf) iz Zelenike 12. veljače 1915. godine.

187 Pod ovim naslovom nije pronađena ni jedna publikacija u katalozima hrvatskih knjižnica. Naručio ju je Nikolaus Jeličić (SMS Kronprinz Erzherzog Rudolf) iz Zelenike 12. veljače 1915. godine.

188 Ljubomir RADIĆ, Ban Jelačić, hrvatski narodni junak od godine 1848.: slika iz brvatske povjesti, Varaždin, 1906. Naručio ju je Nikolaus Jeličić (SMS Kronprinz Erzherzog Rudolf) iz Zelenike 12. veljače 1915. godine. 
primjerka naručeno je filozofsko Schopenhauerovo djelo $O$ ženama. Metafizika polne ljubavi. ${ }^{189} \mathrm{U}$ djelu $O$ ženama. Metafizika polne ljubavi Schopenhauer ženu stavlja u podređeni položaj u odnosu na muškarca, smatrajući da je intelektualno slabija i manje sposobna te da je njezina jedina uloga produžetak vrste. ${ }^{190}$ Prva desetljeća 20. stoljeća obilježena su borbom žena za pravo glasa i sufražetskim pokretima, stoga je ovaj naslov u potražnji vojnika svakako vrijedan spomena. Od publikacija psihološkog sadržaja naručene su dvije (Ljubav poglavito sa psihologijskog stajališta ${ }^{191}$ i Gdje je izvor ljubavnom osjećaju? ${ }^{192}$ ), kao i onih iz područja umjetnosti (Škola za tamburanje ${ }^{193}$ i Uputa u fotografiju ${ }^{194}$ ).

Vojnici su, kao što je prikazano, u najvećem broju naručivali beletristiku, a zatim publikacije religioznog sadržaja. Sve ostale publikacije naručene su u znatno manjem broju primjeraka. Uzrok tomu može biti činjenica da je austrougarska mornarica bila dobro opskrbljena stručnim publikacijama koje su vojnicima bile dostupne u vojnim i brodskim knjižnicama. Pojedinačne narudžbe uključivale su veliki broj naslova ili je isti naslov naručen u više primjeraka, što znači da su pojedinci naručivali publikacije za više naručitelja. Primjerice, takve su narudžbe Antuna Miculinića koji je naručio čak 41 publikaciju, ${ }^{195}$ Jakova Grabara koji je naručio 34 publikacije ${ }^{196}$ ili Petra Ostojića koji je naručio 30 publikacija, a malo je vjerojatno da su sve bile za osobnu upotrebu jer su neke naručene i u više primjeraka. ${ }^{197}$ Mijo Pavić iz Risana tražio je popust na svoju narudžbu jer je naručio dvanaest primjeraka naslova Kita duhovnoga cvieća ${ }^{198}$ Neki vojnici su knjižari uputili i više od jedne narudžbe, a izražavali su i zadovoljstvo kupljenim publikacijama, tako primjerice Franjo Siminiatti iz Pule piše: „Budući da sam

189 Artur Šopenhauer, O ženama. Metafizika polne ljubavi. O časti, Beograd, 1913. Naručili su je Ivan Nešković (SMS Kaise Karl IV) iz Pule 20. studenoga 1915. godine i Jakov Grabar iz Herceg Novog 14. siječnja 1916. godine.

190 Hrvoje Jurić, Svijet kao samovolja i predrasuda: Schopenhauer o spolnosti i o ženama, Filozofska istraživanja, sv. 4, Zagreb, 2005., 791 - 804.

191 Pavao Jemeršić, Ljubav: (poglavito sa psihologijskog stajališta), Zagreb, 1909. Djelo je naručio vojnik Milan Hurbatvinski (SMS Leopard) iz Pule 18. srpnja 1916. godine.

192 Hugo Prugovečki, Gdje je izvor ljubavnom osjećaju?: (crtica iz psihologije eksperimentalne), Zagreb, 1899. Naručio Antun Miculinić iz Pule (SMS Delta Minerva) 5. travnja 1915. godine.

193 V. Matić, Škola za tamburanje, Zagreb, 1903. Naručio Viktor Krišković (SMS Budapest) iz Herceg Novog 9. ožujka 1915. godine.

194 Juraj Božıčević, Uputa u fotografiju, Zagreb, 1909. Naručio Ivo Ivčević iz bolnice u Risanu 1. listopada 1915. godine.

195 Narudžba Antuna Miculinića (SMS Delta, Minerva) iz Pule od 5. travnja 1915. godine.

196 Narudžba Jakova Grabara iz Herceg Novog od 14. siječnja 1916. godine.

197 Narudžba Petra Ostojića (SMS Radetzky) iz Pule od 10. rujna 1915. godine.

198 Narudžba Mije Pavića iz Risana od 5. rujna 1915. godine. 
primio Vaš poslani Samouk njemačkog jezika i budući mi se veoma dopada te Vas najponiznije molim da mi pošaljete još 2 komada te Vam novac odmah šaljem. "199 Vojnici su zasigurno jedni drugima posuđivali knjige, razgovarali o njima te preporučivali naslove. O ponudi knjiga u Knjižari Morpurgo doznavali su putem prodajnih kataloga koje je knjižara objavljivala i besplatno slala zainteresiranim kupcima, ali i usmenom predajom. Tako je Ivan Vrsaljko iz Boke Kotorske naručio Život kraljice Olive pišući da traži izdanje „ne malo, nego s više stranica“ i da ga nije pronašao u katalogu, ali da mu je rekao jedan vojnik s broda Lika da ga knjižara ima. ${ }^{200}$ Narudžbe vojnika koji su imali viši čin, a samim time i veća primanja ${ }^{201}$ i viši stupanj obrazovanja, razlikovale su se od narudžbi običnih vojnika. Primjerice, zapovjednik M. Marušić iz Boke Kotorske 1915. godine naručio je Izabrane pjesme S. S. Kranjčevića, a ne narodne i druge pjesmarice kakve su naručivali vojnici bez čina. Dubljom analizom pojedinačnih narudžbi razotkrivaju se i osobne preokupacije kupaca, primjerice potreba za edukacijom (udžbenici, lingvistički priručnici), briga za zdravlje (zdravstveni priručnici), želja za uspjehom u osobnim odnosima (brošure o bračnom i ljubavnom životu), potreba za duhovnošću (molitvenici), provođenje slobodnog vremena (romani, pripovijetke, pjesmarice) itd. Sve navedeno potvrđuje da su se čitateljski interesi pripadnika austrougarske vojske razlikovali i da su bili određeni prvenstveno stupnjem njihova obrazovanja, pismenošću, a zatim i osobnim aspiracijama. Osim toga, specifične ratne okolnosti u kojima su živjeli i radili, kao i fizička izoliranost (brodovi, vojne baze, bolnice), zasigurno su utjecali i na izbor štiva koje su birali za čitanje.

Sačuvane narudžbe vrijedan su povijesni izvor o čitanju pripadnika austrougarske vojske za vrijeme Prvog svjetskog rata jer otkrivaju tko su bili čitatelji, što su čitali, kada i gdje, a ponekad i razloge njihova čitateljskog interesa (zašto). Međutim, iz njih se rijetko može iščitati ono što suvremene povjesničare čitanja najviše zanima, a to je način čitanja (kako) i recepcije

199 Narudžba Franje Siminiattija iz Pule od 1. studenoga 1916. godine, HR-DAST-94 MOR. 11/III.

200 Narudžba Ivana Vrsaljka (SMS Wien) iz Boke Kotorske od 19. ožujka 1915. godine, HR-DAST-94 MOR. 10/V.

201 Vojnička plaća ovisila je, naravno, i o činu. Godišnja plaća poručnika iznosila je 600 fiorina (1200 kruna), pukovnika 3000 fiorina (6000 kruna), generala 8400 fiorina (168000 kruna) itd. Tado Oršolić, Vojna Dalmacija u 19. stoljeću: vojska, teritorijalne snage, žandarmerija (1797.-1914.), Zadar, 2013., 251 - 254. Dočasnici i obični vojnici bili su mnogo manje plaćeni u odnosu na časnike. Plaće običnih vojnika iznosile su oko 100 fiorina (200 kruna) godišnje (plus ratne naknade u iznosu 5 - 15 fiorina). Tado ORŠolić, „O časničkoj izobrazbi, plaći i časničkom kadru u Austro-ugarskoj vojsci s naglaskom na Dalmaciju“, Radovi Zavoda za povijesne znanosti HAZU u Zadru, sv. 48, Zadar, 2006, $557-568$. 
teksta. Dnevnički zapisi, memoari, korespondencija i drugi izvori kojima su se koristili inozemni povjesničari knjige i čitanja otkrivaju da su vojnici prakticirali čitanje u sebi, ${ }^{202}$ ali i glasno čitanje u prisustvu više osoba. ${ }^{203}$ Otkrivaju i da su vojnici diljem europskih bojišnica čitali ponajprije iz zabave i dosade, ${ }^{204} \mathrm{da}$ im je čitanje odvraćalo misli od rata, bilo svojevrstan vid eskapizma i podsjećalo ih na njihov predratni, mirnodopski identitet, ${ }^{205}$ ali i da su čitali zbog jačanja morala i pobjedničkog duha, ${ }^{206}$ obrazovanja radi, ${ }^{207}$ osobito potkraj rata kada se trebalo vratiti svakodnevici i uobičajenim mirnodopskim aktivnostima i poslovima, ${ }^{208}$ ali i zbog toga što su knjigu doista držali duhovnom hranom, ${ }^{209}$ a katkad i iz sasvim prozaičnih razloga, kao što je bila zaštita od buke i žamora u zatvorskim sobama ${ }^{210}$ ili pak jer su u knjigama pronalazili opise svega onoga što im je u ratu, u vrijeme gladi, neimaštine i odvojenosti od obitelji, nedostajalo. ${ }^{211}$ Izvori u kojima bi se mogli pronaći takvi podatci zasigurno bi pružili potpuniji i slikovitiji uvid u čitateljske prakse vojnika austrougarske mornarice.

202 E. G. C. KING, Books are more to me than food, 263.

203 E. G. C. KING, Books are more to me than food, 263; E. G. C. KING, E. W. Hornung's Unpublished „Diary“, 379.; R. L. Nelson, Soldier Newspapers, 180.

204 E. G. C. KING, Books are more to me than food, 246, 261; E. G. C. KING, E. W. Hornung's Unpublished „Diary“, 364; R. L. Nelson, Soldier Newspapers, 172, 180.

205 Knjiga je postala simbolom obiteljskog i civilnog života. „Čin čitanja, samo prelistavanje knjige ili sâmo držanje knjige, omogućavalo je vojniku da okupira svoj um, da spriječi naviranje neželjenih misli, osobito u trenucima kada je fizičko kretanje bilo ograničeno, poput razdoblja dužih bombardiranja.“ E. G. C. KInG, E. W. Hornung’s Unpublished „Diary“, 364, 376. Prema: Alexander Watson, Enduring the Great War: Combat, Morale and Collapse in the German and British Armies, 1914-1918., Cambridge, 2008., 105; E. G. C. KING, Books are more to me than food, 265 - 266; R. L. Nelson, Soldier Newspapers, 172, 181; A. Laugesen, Finding „Another Great World“, 424, 434.

206 Tu su misiju ponajprije imale vojničke i rovovske novine. R. L. NELson, Soldier Newspapers, 172.

207 E. G. C. KING, Books are more to me than food, 249.; E. G. C. KING, E. W. Hornung's Unpublished „Diary“, 364.

208 A. Laugesen, Finding „Another Great World“, 426.

209 E. G. C. KING, Books are more to me than food, 253. Smatralo se da je čitanje „vid okrepljujućeg sredstva koji im je omogućavao da svoje vojničke dužnosti izvršavaju obnovljenih snaga“. E. G. C. KING, E. W. Hornung's Unpublished „Diary“, 371.

210 E. G. C. KING, Books are more to me than food, 262.

211 Tako u svojim memoarima Alec Waugh navodi da je jedan časnik čitao Blackmoreov roman Lorna Doone, Dickensov The Pickwick Papers i Dellov The Knave of Diamonds samo zbog opisa „velikih obroka i luksuza“ koje su sadržavali. E. G. C. KING, „Books are more to me than food“, 258. Alec Waugh, Prisoners of Mainz, London, 1919., 53 - 54. 


\section{ZAKLJUČAK}

Obilježavanje stote obljetnice Prvog svjetskog rata povećalo je interes za ratnom svakodnevicom, pa tako i čitanjem vojnika, heterogene kategorije stanovništva koja se formirala regrutiranjem muškaraca iz različitih društvenih slojeva. Za razliku od inozemnih istraživača koji su pokazali veliki interes za vojničke čitateljske prakse, među malobrojnim radovima posvećenim povijesti čitanja u Hrvatskoj potpuno izostaju oni koji bi se bavili čitanjem vojnika. U istraživačkom dijelu ovog rada detaljno su prikazane narudžbe koje su pripadnici austrougarske mornarice uputili splitskoj Knjižari Morpurgo tijekom prve dvije godine Prvog svjetskog rata (1914. - 1916.), a koje su autentično svjedočanstvo o njihovim čitateljskim interesima. Iako malobrojne (113), ove narudžbenice otkrivaju niz podataka o vojnicima kao čitateljima: njihova imena, status, imena brodova i vojnih baza u kojima su bili smješteni i, što je najvažnije, naslove publikacija koje su naručivali, pa čak i razloge zbog kojih su ih naručili, a onda, pretpostavljamo, i čitali. Utvrđeno je da su najveći broj narudžbi knjižari uputili hrvatski pripadnici mornarice čiji je udio u austrougarskoj mornarici i bio najveći. Najveći broj narudžbi pristigao je iz Pule i Herceg Novog, ali i ostalih gradova i mjesta u kojima je bila stacionirana mornarička flota na Jadranu, i to iz redova običnih vojnika i vojnika nižeg čina. Jezična analiza naručenih publikacija pokazala je da su vojnici uglavnom naručivali knjige pisane hrvatskim jezikom, a interes su pokazivali i za jezičnim priručnicima za učenje njemačkog i talijanskog jezika kojim su govorili njihovi nadređeni. Moguće je da je hrvatski bio jedini jezik koji su poznavali ili da su im publikacije na stranim jezicima bile dostupne u mornaričkim posudbenim knjižnicama i čitaonicama pa su ih zato naručivali u manjem broju. Tematska i žanrovska analiza naručenih publikacija otkrila je da su vojnici najviše naručivali publikacije iz područja književnosti (pjesmarice, romane, pripovijetke) i religije (molitvenike) te da se njihovi čitateljski interesi nisu mnogo razlikovali od onih njihovih suvremenika u ostalim europskim vojnim postrojbama. Potrebe za stručnim publikacijama zasigurno su zadovoljavali u dobro opskrbljenim mornaričkim knjižnicama. Rijetke pojedinačne zabilješke na narudžbenicama donose i dodatne podatke koji otkrivaju da je Knjižara Morpurgo bila na dobrom glasu među vojnicima te da su vojnici međusobno posuđivali knjige te ih jedni drugima preporučivali. Ponekad su izbor publikacije prepuštali knjižaru okvirno navodeći koja ih literatura zanima i iz kojeg razloga.

Narudžbenice upućene Knjižari Morpurgo prvenstveno otkrivaju pojedinačne čitateljske interese vojnika. Međutim, analiza naručenih publikacija pokazala je da je njihovo čitanje imalo i zajednička obilježja koja 
se očituju u interesu za beletristikom i vjerskim publikacijama. Posljedica je to sličnih životnih uvjeta u ratnim prilikama i činjenice da su vrijeme provodili izolirani u vojnim bazama, bolnicama (ranjenici) i na brodovima gdje je čitanje predstavljalo korisno upotpunjavanje slobodnog vremena, razonodu, edukaciju, informiranje, utjehu, a ponekad i svojevrstan bijeg od ratne stvarnosti.

Istraživanja koja bi uključivala i druge izvore (dnevničke zapise, korespondenciju, novinske članke, posudbene statistike mornaričkih knjižnica...) sigurno bi dala jasniju i širu sliku vojničkih čitateljskih praksi, međutim i ovaj kratki prikaz može poslužiti kao prvi uvid i korak u njihov čitateljski svijet. 
Jelena LAKUŠ, Nada TOPIĆ

\section{MEMBERS OF AUSTRO-HUNGARIAN NAVY AND READING DURING WORLD WAR ONE: THE EXAMPLE OF MORPURGO BOOKSTORE IN SPLIT}

\section{SUMMARY}

Characteristics of reading practices, reading experiences and habits of members of Austro-Hungarian Navy during World War One have so far remained almost a complete mystery to us. This paper, which rests on a detailed analysis of 113 order forms sent by members of Austro-Hungarian Navy to the Morpurgo bookstore in Split in the period 1914-1916, and identified at the State Archives in Split, reveals a whole set of information on soldiers as readers: their names, their status, the names of the ships they sailed on and military bases they were positioned at, titles of publications they ordered, and occasionally even their reasons for reading. We have thereby won an interesting and unique insight into the reading profile of soldiers during World War One. The paper offers a linguistic, thematic and genre analysis of the ordered publications; it has been concluded that soldiers had mainly been ordering books written in Croatian language - mostly literature (books of poems, novels, short stories) and religious works (books of prayers), and that their reading interests did not significantly differ from the interests of their contemporaries in other European military units of that time. The analysis of the geographic distribution of the orderers showed that the majority of orders came from Pula, the central port of AustroHungarian Navy, but there were also orders from other towns and settlements where the navy fleet on the Adriatic was stationed (Herceg Novi, Crkvice, Risan, Šibenik, etc.). The orderers were in most cases privates and soldiers of lower ranks, of Croatian nationality in most cases. The paper endeavours to show that the analyzed order forms are not only an authentic testimony regarding the soldiers' interest in reading, but also a genuine historical trace of the need for written word and for books in the wartime.

Keywords: soldiers; Austro-Hungarian Navy; World War One; Morpurgo bookstore; reading; reading culture. 